\title{
Source Apportionment of Carbon During Gasification of Coal-Biomass Blends Using Stable Carbon Isotope Analysis
}

\author{
Abhijit Bhagavatula ${ }^{\mathrm{a}, *}$, Gerald Huffman ${ }^{\mathrm{a}}$, Naresh Shah ${ }^{\mathrm{a}}$, \\ Christopher Romanek ${ }^{\mathrm{b}}$, Rick Honaker ${ }^{\mathrm{c}}$
}

\begin{abstract}
Stable carbon isotope analysis, a unique analytical technique, has been utilized for distinguishing and quantifying the individual contributions of coal and biomass feedstock materials in the generation of carbon containing gases during the gasification of their blends. For this purpose, two different biomass samples, namely, corn stover (CS) and switchgrass (SG), were physically blended up to $30 \%$ by weight with two different Montana rank coals, namely, DECS-38 sub-bituminous coal (SB) and DECS-25 lignite coal (LG). The blended samples were then gasified in a moving bed gasifier operating at atmospheric pressure and varying $\mathrm{O}_{2} /$ steam ratios. The ratio of $\mathrm{CO} / \mathrm{CO}_{2}$ in the product gas decreased with decreasing $\mathrm{O}_{2} /$ steam ratio and increasing amount of biomass in the blends. Gasifying at a constant $\mathrm{O}_{2} /$ steam ratio with increasing percentage of biomass in the feedstock, resulted in an increasing trend of $\delta^{13} \mathrm{C}$ (\%o)
\end{abstract}


values for the carbon containing product gases. An increase in the concentration of oxygen in the feed stream at a constant biomass percentage leads to the depletion of ${ }^{13} \mathrm{CO}$ and enrichment of ${ }^{13} \mathrm{CO}_{2}$ in the blends with corn stover while an enrichment of both ${ }^{13} \mathrm{CO}$ and ${ }^{13} \mathrm{CO}_{2}$ was observed in blends with switchgrass. For blends with corn stover, there exists the possibility of a carbon isotope equilibrium between $\mathrm{CO}$ and $\mathrm{CO}_{2}$ only at temperatures over $1000{ }^{\circ} \mathrm{C}$ at an $\mathrm{O}_{2}$ :steam ratio of 2:1 and corn stover percentage not exceeding $20 \%$ while for blends with switchgrass, the gases are not in isotopic equilibrium. Based on isotope mass balance considerations, for the operating conditions utilized, the contribution of corn stover was in the range of $1 \%-40 \%$ for $\mathrm{CO}$ generation and $6 \%-69 \%$ for $\mathrm{CO}_{2}$ generation. Switchgrass, on the other hand, contributed up to $53 \%$ for $\mathrm{CO}$ generation and only $46 \%$ for $\mathrm{CO}_{2}$ generation.

Keywords: Coal-Biomass Blends; Gasification; Stable Carbon Isotope Analysis; Source Apportionment. 


\section{Introduction}

The past few years have seen an upsurge in interest in the gasification of biomass and coal-biomass blends for several reasons. They include [1]:

1. Reduction in greenhouse gas emissions caused by the combustion of fossil fuels.

2. A need for energy independence due to the depleting resources and fluctuating prices of oil and natural gas.

3. Developing interest in renewable energy resources.

Although there is an abundance of coal in the United States and several other countries and it will continue to be a major source of energy for many years to come, there is still great interest in replacing part of the coal used in energy generation with renewable biomass or plant-derived organic matter available on a renewable basis [2]. Many countries have initiated incentives in recent years to encourage the co-utilization of biomass and coal for energy production [3]. Biomass fuels $(\mathrm{BF})$ are to be sustainable natural resources if they renew themselves at such a rate that they will be available for future use. That is, if the rate of consumption of BF is $\leq$ the rate at which it is generated. These BF resources can be either grown and harvested biomass such as switchgrass or waste biomass such as corn stover, wood wastes from forestry and lumbering operations, wastes from paper production, and landscaping wastes [2].

There are various techniques available for coal gasification. Considering the huge amount of greenhouse gases generated during the process of gasification, new methods are being developed [4]. The idea of gasifying mixtures of coal and biomass is relatively new with almost zero commercial experience since the properties of coal and biomass differ significantly from each other [5-8]. Co-processing these feedstocks, with oxygen and steam in relevant proportions with respect to the amount of carbon results in the formation of mainly $\mathrm{CO}, \mathrm{CO}_{2}, \mathrm{H}_{2}$ and small 
quantities of lower hydrocarbons. Prins et al. [9] reported that fuels with higher oxygen to carbon ratios have larger energy losses due to their high ratio of available chemical energy to heating value. Such fuels are over-oxidized (combusted) in the gasifier to attain the required gasification temperature. Therefore, highly oxygenated fuels are not ideal for gasifiers keeping in view the energy losses that can be incurred and hence, solid biomass can be more readily gasified if it is co-gasified with coal [3]. Hence, co-gasification of blends of coal and biomass to produce syngas $\left(\mathrm{CO}-\mathrm{H}_{2}\right.$ mixtures) is an open area for future research. The $\mathrm{CO}_{2}$ generated during the combustion of $\mathrm{BF}$ is neutralized by the utilization of atmospheric $\mathrm{CO}_{2}$ through photosynthesis during biomass growth. Therefore, it is imperative to quantify the contribution of these biomass feedstocks in the generation of greenhouse gases. Stable carbon isotope analysis is one such technique that can be utilized to know the source of gases generated during co-processing [1013].

\section{Theory}

Stable carbon isotope composition is determined as the ratio of ${ }^{13} \mathrm{C} /{ }^{12} \mathrm{C}$ in a substance relative to Pee Dee Belemnite (PDB), a cretaceous marine fossil having an anomalously high ${ }^{13} \mathrm{C} /{ }^{12} \mathrm{C}$ ratio, which is an internationally established reference standard for the stable isotope composition of carbon in natural materials. Carbon isotope ratios are commonly reported using delta notation (as $\delta^{13} \mathrm{C}$ values) in parts per thousand (per mil, \%o) $[10,11,14-21]$ as shown in Equation 1.

$$
\delta^{13} C=\left(\frac{\left({ }^{13} C /{ }^{12} C\right) \text { sample }}{\left({ }^{13} C / 12 C\right) \text { standard }}-1\right) \times 1000 \%
$$


Most plants can be divided into three groups based on the photosynthetic pathway by which they fix carbon [22-24]:

1. $\mathrm{C}_{3}$ : Almost $95 \%$ of the plants on earth fall under this category. They fix carbon dioxide by the Calvin cycle and have $\delta^{13} \mathrm{C}$ values that generally range between -23 and $-34 \%$. Examples of these plants include temperate shrubs and trees, and grasses.

2. $\mathrm{C}_{4}$ : These plants fix carbon dioxide by the Hatch-Slack cycle. Their $\delta^{13} \mathrm{C}$ values are less negative and range between -8 and $-16 \%$. Plants like corn, switchgrass and warm weather grasses, predominantly, belong to this category.

3. CAM: The third group of plants fix carbon dioxide by the Crassulacean Acid Metabolism pathway, and have $\delta^{13} \mathrm{C}$ values that are intermediary compared with $\mathrm{C}_{3}$ and $\mathrm{C}_{4}$ plants.

Fossil fuels such as coal and oil are made primarily of $\mathrm{C}_{3}$ plant material and are depleted in ${ }^{13} \mathrm{C}$ relative to the atmosphere, because they were originally formed from living organisms [21, 25]. Therefore, the carbon from fossil fuels that is returned to the atmosphere through combustion is depleted in ${ }^{13} \mathrm{C}$ when compared to atmospheric carbon dioxide. The values of $\delta^{13} \mathrm{C}$ vary by measurable amounts for different carbonaceous materials depending on their carbon source, fixation pathway, environment of formation and post depositional history. These values differ by about $10-15 \%$ for coal and biomass materials with the $\delta^{13} \mathrm{C}$ for coal being more negative than that of biomass. This means that the carbon contained in coal is richer in ${ }^{12} \mathrm{C}$, as is the case with all fossil fuels. Surprisingly, the carbon isotope composition of coal typically does not vary much with increasing coal rank which implies that significant fractionation does not occur during its decomposition $[21,25,26]$. 
Most of the previous works involving coal co-processing that utilizes isotope mass spectrometry are related to the sourcing of coal-bitumen or coal-oil co-processing or gasification of carbon composite materials [14-17, 26, 27]. Steer et al. [17] studied the efficacy of Highvale coal and Suncor bitumen co-processing using this technique and provided a valid isotope mass balance method to quantify the amount of coal incorporated in each distillate fraction of their liquefaction process [17]. The synthetic oil generated from their process had intermediate isotope ratios which were directly proportional to the amount of coal incorporated in the feedstock. Lancet et al. [15, 16] and Winschel et al. [27] determined the individual contributions of various coal/petroleum feedstocks under varied conditions and demonstrated that stable carbon isotope analysis can be a quantitative tool to independently assess the relative reactions of carbonaceous feedstocks during co-processing $[15,16,27]$. In these studies, the isotope ratios of product gas samples were not obtained directly; instead, a forced carbon balance was utilized to obtain information on the gas products. These studies concluded that during actual co-processing, considerable bond breaking occurs. Because ${ }^{13} \mathrm{C}-{ }^{12} \mathrm{C}$ bonds are slightly stronger than ${ }^{12} \mathrm{C}-{ }^{12} \mathrm{C}$, heavier organic residues like tar and vacuum bottoms were presumed to be enriched in ${ }^{13} \mathrm{C}$ while lighter hydrocarbon gas products were enriched in ${ }^{12} \mathrm{C}$ relative to the feed. Therefore, the isotope ratios in such cases would never be intermediate to the parent sources. Further complications may arise if isotope ratios in product materials change over time depending on the extent of the reactions. For cases in which the generation of light hydrocarbons such as methane is very low and when isotopic mass balances are not affected in a huge way, the isotope analysis would still be very useful for envisaging product trends that occur during co-processing. Thomas et al. [26] performed isotope ratio mass spectrometry to study the gasification of carbon composites manufactured from the co-processing of coal tar pitch fibers and petroleum pitch matrix. They 
observed that heat treating the composite produced changes in the carbon isotope composition of the reactant which may be due to different $\delta^{13} \mathrm{C}$ values for the product gas and solid phases. Partially gasifying the carbon composites lowered their $\delta^{13} \mathrm{C}$ values by about $4 \%$ due to the loss of ${ }^{12} \mathrm{C}$ enriched gases such as methane and that the $\delta^{13} \mathrm{C}$ values for the composites change as function of gasification temperature. Also, the products had intermediate $\delta^{13} \mathrm{C}$ values compared with the parent materials and hence, reactions occurring during co-processing were easily distinguishable [26].

This paper describes the utilization of stable carbon isotope analysis for distinguishing and quantifying the individual contributions of coal and biomass feedstocks towards the generation of carbonaceous product gases, in particular, $\mathrm{CO}$ and $\mathrm{CO}_{2}$. Although this application has been available for many years and used mostly in bio-geo-chemical studies, very limited information is available in literature with regards to this particular analysis for blends of coal and biomass. Experimental data obtained by this method can provide valuable information for analyzing the interactions and synergy between the feedstocks and also for process modeling and optimization of production methods.

\section{Experimental}

\subsection{Materials}

For the purpose of this work, two different biomass samples, namely, corn stover (CS) and switchgrass (SG) were blended individually up to $30 \%$ by weight with two different ranks of non-composite Montana coals, namely, DECS-38 sub-bituminous coal (SB) and DECS-25 lignite coal (LG) [28]. The US Department of Energy Coal Samples (DECS) used in this work were obtained from The Pennsylvania State University Coal Sample Database while the biomass 
samples were provided by the Center for Applied Energy Research at the University of Kentucky. The DECS-38 sub-bituminous coal was collected from Dietz seam of Bighorn County while the DECS-25 lignite coal was collected from Pust seam of Richland County located in Montana, USA [28]. Detailed information regarding coal sample history, sampling information from the coal field, maceral composition and reflectance data is available through The Pennsylvania State University Coal Sample Database [28].

The proximate and elemental analysis of all the feedstock samples are listed in Table 1. Proximate analysis of the feedstock samples was conducted according to ASTM standard D7582-12 [29] using a Netzsch Jupiter STA 449 Simultaneous Thermal Analyzer. The percentages of $\mathrm{C}, \mathrm{H}$, and $\mathrm{N}$ in the feedstock samples were determined according to ASTM standard D5373-08 [30] using a LECO 628 Series Carbon/Hydrogen/Nitrogen Analyzer comprising of a dual-stage furnace operating at $1050^{\circ} \mathrm{C}$ while the percentage of sulfur in the sample was determined according to ASTM standard D4239-12 [31] using LECO SC 632 Carbon and Sulfur Analyzer and oxygen percentage obtained by difference. The samples were crushed and sieved to $150 \mu \mathrm{m}$ before blending to limit the effects of intra-particle heat transfer. The coal-biomass blends were prepared in appropriate proportions and homogenized by constant stirring in the sample holders to ensure sufficient dispersion.

Based on the proximate and elemental analyses (As-Received basis) of the feedstocks listed in Table 1, Montana coals can be considered to be fairly high moisture content ( 22 to 35 wt \%) and relatively low ash content (3.75 to $7.71 \mathrm{wt} \%)$ coals with the lower values corresponding to DECS-38 sub-bituminous coal. The volatile matter present in these coals varied between $27 \%$ and $35 \%$ while the fixed carbon content ranged between $30 \%$ and $40 \%$. The total carbon content approximately varied between $43 \%$ and $57 \%$ (higher values correspond to 
DECS-38 sub-bituminous coal). In contrast, the biomass materials have low moisture ( $5 \mathrm{wt} \%)$ and fixed carbon content ( $10 \mathrm{wt} \%)$ while displaying very high percentage of volatile matter ranging between 76 and $84 \mathrm{wt} \%$.

These feedstocks were then gasified in a moving bed gasifier operating at atmospheric pressure and varying $\mathrm{O}_{2}$ /steam ratios. Gasification of blends of higher percentages of biomass (in excess of $30 \%$ by weight) was not possible for the conditions at which the gasifier was operated since biomass is a low density, low heating value fuel and addition of more biomass would make the gasification process less efficient. Hence, a maximum of $30 \%$ by weight of biomass was chosen for this process.

\subsection{Process Parameters and Reactions}

The gasification of the feedstock materials was performed at atmospheric pressure using three different volumetric ratios of $\mathrm{O}_{2}$ :steam $\left(0.5,1.0\right.$ and 2.0) which correspond to an $\mathrm{O}_{2}$ :steam mass ratio of 1.0, 2.0 and 4.0, respectively. One hundred grams of solid feedstock was gasified during each experimental run. The oxygen flowrate was maintained constant at $650 \mathrm{ml} / \mathrm{min}$ while the flowrate of steam was maintained between $325 \mathrm{ml} / \mathrm{min}$ to $1300 \mathrm{ml} / \mathrm{min}$ and the corresponding product gas compositions obtained. The $\mathrm{O}_{2} /$ solid feedstock mass ratio was, therefore, constant at 0.625 while the corresponding steam/solid feedstock mass ratios were $0.624,0.312$ and 0.156 , respectively. For the purpose of discussion, the $\mathrm{O}_{2}$ :steam ratios are further presented as volumetric ratios.

An increase in the $\mathrm{O}_{2}$ :steam ratio was seen to result in an increase in the gasification temperature. Since, the gasification was performed auto-thermally, it was necessary that the percentages of oxygen and steam were varied in such a way so as to not let the endothermic zone dominate. Therefore, a minimum $\mathrm{O}_{2}$ :steam ratio of 0.5:1 was utilized, below which endothermic 
zone would prevail and the gasification would not proceed further. The product gas compositions (response variables) were analyzed in two ways: (1) by varying the $\mathrm{O}_{2}$ :steam ratios at constant biomass wt $\%$ and, (2) by varying the biomass wt $\%$ at constant $\mathrm{O}_{2}$ :steam ratios (treatment factors). Each experimental run was replicated 5 times $(n=5)$ and average product gas compositions were obtained within $95 \%$ confidence interval. A list of all the treatment factors and response variables along with values of standard deviations for product gas compositions is provided in Table 2 .

In any gasifier, char gasification takes place following coal pyrolysis. The remaining carbonaceous solids from the pyrolysis reactions are further oxidized through heterogeneous reactions with carbon dioxide, carbon monoxide, steam, oxygen, and hydrogen. The major reactions that occur during the gasification process are described in Equations 2 through 8.

Combustion $\left\{\begin{array}{lll}\mathrm{C}+\mathrm{O}_{2} \rightarrow \mathrm{CO}_{2} & \Delta \mathrm{H}=-394 \mathrm{~kJ} / \mathrm{mol} \\ \mathrm{C}+1 / 2 \mathrm{O}_{2} \rightarrow \mathrm{CO} & \Delta \mathrm{H}=-111 \mathrm{~kJ} / \mathrm{mol} \\ \mathrm{CO}+1 / 2 \mathrm{O}_{2} \rightarrow \mathrm{CO}_{2} & \Delta \mathrm{H}=-283 \mathrm{~kJ} / \mathrm{mol}\end{array} \quad\right.$ (Equation 2)

$\left.\begin{array}{l}\text { Boudouard Reaction } \\ \text { Vapo-gasification } \\ \text { Water gas shift } \\ \text { Methanation }\end{array}\right\} \begin{array}{lll}\mathrm{C}+\mathrm{CO}_{2} \leftrightarrow 2 \mathrm{CO} & \Delta \mathrm{H}=+172 \mathrm{~kJ} / \mathrm{mol} \\ \mathrm{C}+\mathrm{H}_{2} \mathrm{O} \leftrightarrow \mathrm{CO}+\mathrm{H}_{2} & \Delta \mathrm{H}=+131 \mathrm{~kJ} / \mathrm{mol} \\ \mathrm{CO}+\mathrm{H}_{2} \mathrm{O} \leftrightarrow \mathrm{CO}_{2}+\mathrm{H}_{2} & \Delta \mathrm{H}=-41 \mathrm{~kJ} / \mathrm{mol} \\ \mathrm{C}+2 \mathrm{H}_{2} \leftrightarrow \mathrm{CH}_{4} & \Delta \mathrm{H}=-75 \mathrm{~kJ} / \mathrm{mol}\end{array} \quad$ (Equation 7)

Sensible heating of the hot gas provides the heat required for the two endothermic gasification reactions given by Equations 5 and 6 . These are responsible for most of the gasification products like hydrogen and carbon monoxide. Equation 7, known as the water gas 
shift reaction, is an exothermic reaction and has an effect on the $\mathrm{H}_{2} / \mathrm{CO}$ ratio of the gasification product which is very important when the gas is used for synthesis in downstream processes such as Fischer-Tropsch synthesis. High conversion of $\mathrm{CO}$ and steam to $\mathrm{CO}_{2}$ and $\mathrm{H}_{2}$ is favored at low temperatures.

The reaction of char with hydrogen to produce methane proceeds at a very slow rate except at very high pressures which is not the case in this study and hence very low concentrations of methane are observed in all the experiments that were performed.

\subsection{Apparatus}

A laboratory-scale updraft gasification system, shown in Figure 1, was designed and constructed for this study. The gasifier is a 3 feet long cylindrical stainless steel modular flange assembly having an internal diameter of 1.37 inches fitted with another stainless steel tube of 0.075 inches thick on the inside to promote better heat transfer in the axial direction. Temperature profiles along the gasifier axis are measured by a set of K-type thermocouples placed within a steel protective tube.

Coal/biomass is fed at the top of the gasifier by means of a quick-open flange while oxygen and steam are introduced from the bottom of the gasifier at atmospheric pressure. The design utilizes a single condenser wherein the hot outlet gas at a temperature of approximately $120{ }^{\circ} \mathrm{C}$ enters a cold zone maintained at a temperature of about $10{ }^{\circ} \mathrm{C}$ so that unreacted water and other solids can be removed efficiently ensuring that clean product gas which is a mixture of hydrogen, carbon monoxide, carbon dioxide and small amounts of methane, is analyzed using a GOW-MAC Series 600 Auto System GC equipped with a dual thermal conductivity detector (TCD). Nitrogen was used as the carrier gas for the isothermal separation of diatomic hydrogen 
using a packed HAYESEP Q 60/80 column (4 feet), while helium was used for the isothermal separation of all other carbonaceous gases using a packed HAYESEP N 60/80 column (9 feet). Both carrier gases were regulated at $30 \mathrm{ml} / \mathrm{min}$ and analytes were detected every 6 minutes. The temperature of the thermal conductivity detector was maintained constant at $150{ }^{\circ} \mathrm{C}$ while the columns were constant at $140{ }^{\circ} \mathrm{C}$.

The first step in the gasification process is the ignition of the bed by adding small amounts of externally heated charcoal particles onto the gasifier bed while supplying the oxidant at a low flow rate of approximately $100 \mathrm{ml} / \mathrm{min}$ to $150 \mathrm{ml} / \mathrm{min}$. The feed material is then added onto the charcoal particles and the oxidant flowrate is increased, causing ignition of the bed. Once the bed is ignited, pre-heated steam enters the bed from the bottom of the gasifier. The outlet of the GC is connected to a 500 cc TEDLAR gas sampling bag using a two-way valve. Once the oxygen in the product gas stream is depleted, the valve is opened so that the product gases are collected in the sampling bag. The collected gases are then analyzed for their isotopic composition using GC-C-IRMS.

The GC-C-IRMS analyses were performed using a modified Thermo Fisher Trace GC Ultra connected to a Delta ${ }^{\text {PLUS }} \mathrm{XP}$ isotope ratio mass spectrometer by GC Isolink interface. All carbonaceous compounds eluting from the GC column (30 m Carboxen 1010 PLOT column) were oxidized to $\mathrm{CO}_{2}$ in a capillary combustion reactor maintained at $1030{ }^{\circ} \mathrm{C}$. Helium, flowing at $0.5 \mathrm{ml} / \mathrm{min}$, was used as the carrier gas while the temperature of the $\mathrm{GC}$ was ramped at a rate of $10{ }^{\circ} \mathrm{C} / \mathrm{min}$ from $50{ }^{\circ} \mathrm{C}$ to $150{ }^{\circ} \mathrm{C}$ and held at that temperature for 30 minutes. The product gas samples from the gasifier were loaded onto the GC using $50 \mu \mathrm{L}$ gas tight syringes through a PVT injector held at $200{ }^{\circ} \mathrm{C}$ in split/splitless mode at a split ratio of 30:1. All isotope analyses were 
performed in duplicate to provide an estimate for precision and the standard deviation obtained for all $\delta^{13} \mathrm{C}$ values was less than $\pm 0.2 \%$ o $(\mathrm{n}=5)$.

\section{Results and Discussion}

The product gas compositions of $\mathrm{CO}$ and $\mathrm{CO}_{2}$ for all experimental runs are shown in Table 2. A major fraction of the product gas contains hydrogen, and methane is also formed in small quantity $\left(\mathrm{CH}_{4}<6 \%\right.$ of total product gas for all experiments).

The $\delta^{13} \mathrm{C}$ values for all the feedstock samples used in this analysis are listed in Table 3. For sourcing applications in co-processing, it is necessary that the co-processing feedstocks, which in this case are coal and biomass, have sufficiently different carbon isotope ratios. The idea is that, two isotopically different materials undergoing thermal degradation in a closed system would generate products that would have an isotopic signature intermediary to the parent materials, thus, reflecting the relative amounts of each material utilized. As it can be seen from Table 3, sub-bituminous coal and lignite coal are similar in isotope composition (-25.31 and $24.71 \%)$ as are corn stover and switchgrass (-11.05 and $-11.13 \%$ ). The difference in the carbon isotope ratios is relatively large between the coals and corn stover/switchgrass when compared to that of softwoods like pine and poplar which have isotopic compositions of -24.62 and $-23.93 \%$ respectively, similar to that of the coals. This is due to the fact that fossil fuels and most woody biomass materials belong to a similar class of biological material (i.e., $\mathrm{C}_{3}$ plants) as discussed earlier. Therefore, corn stover and switchgrass were chosen to be mixed with the coals in different proportions in this study. Under the GC experimental method used, carbon monoxide elutes around 318 seconds after injection followed by methane and carbon dioxide at 606 seconds and 1350 seconds respectively. The amount of methane generated is relatively low and hence it is difficult to quantify its isotopic signature without the injection volume being too large. 
This would require pre-concentration of methane from the sample gas and heavy water tracer tests may be used in such cases to determine the origin of methane [32] which is out of the scope of this work. Therefore, the IRMS analysis is limited to $\mathrm{CO}$ and $\mathrm{CO}_{2}$ which are the major carbon containing gases produced. The $\delta^{13} \mathrm{C}$ values of the gaseous products (i.e., $\mathrm{CO}$ and $\mathrm{CO}_{2}$ ) were analyzed as described in Section 3 and they are listed in Table 4. The isotope values of CO from the gasification of each pure source coal are extremely close to the isotope values of the parent materials and are only slightly more negative by about $0.3 \%$. On the contrary, $\mathrm{CO}_{2}$ under same gasification conditions is enriched in ${ }^{13} \mathrm{C}$ by about $2 \%$ when compared with the source coals. This can be caused due to the effect of isotopic fractionation occurring during gasification. These shifts in isotopic values can be used in the estimation of isotopic equilibrium temperatures and compare them to the actual temperatures attained in the gasifier so as to verify the presence of an isotopic equilibrium between the gaseous compounds.

\subsection{Blends with Corn Stover}

For blends of both coals with corn stover, from Table 2, it may be observed that with a decrease in $\mathrm{O}_{2}$ :steam ratio, the composition of $\mathrm{CO}$ decreases while $\mathrm{CO}_{2}$ remains constant in all experiments indicating that Boudouard reaction (Equation 5), water gas reaction (Equation 6) and water gas shift reaction (Equation 7) may be taking precedence. For instance, in blends of sub-bituminous coal and corn stover, holding the percentage of corn stover constant at $30 \%$ and varying the $\mathrm{O}_{2}$ :steam ratios from 2:1 to $0.5: 1$ results in a significant drop in the fraction of carbon monoxide in the dry product gas from approximately $18 \%$ to $13 \%$ whereas the fraction of carbon dioxide remains fairly constant at approximately $56 \%$. In other words, the ratio of $\mathrm{CO} / \mathrm{CO}_{2}$ decreases with the addition of steam to the gasifier. This can be attributed to the fact that addition of excess steam to the gasifier lowers the temperatures which favors the conversion 
of $\mathrm{CO}$ to $\mathrm{CO}_{2}$ through water gas shift reaction. The gas compositions can also be compared by increasing the corn stover percentage in the blend, and holding the $\mathrm{O}_{2}$ :steam ratio constant. An increase in corn stover percentage yields lower carbon monoxide while increasing the carbon dioxide yield in the product gas. Considering an $\mathrm{O}_{2}$ :steam ratio of $2: 1$, the fraction of carbon monoxide decreases from $32 \%$ to $18 \%$ while carbon dioxide increases from $42 \%$ to $56 \%$ when corn stover is increased from $0 \%$ to $30 \%$ in blends with sub-bituminous coal. This observed effect is significant with confidence intervals greater than $95 \%$. The P-values were calculated by performing an analysis of variance (ANOVA) of the obtained product gas compositions with respect to varying $\mathrm{O}_{2}$ :steam ratios and varying corn stover percentages in the blended feedstock (Section 4.3).

Similar trends are observed in blends of corn stover with lignite coal. A comparison of corn stover blends with sub-bituminous and lignite coal suggests that the ratio of $\mathrm{CO} / \mathrm{CO}_{2}$ is slightly lower in lignite blends. This is because, addition of corn stover to both coals reduces the amount of char reacting in the gasifier and in the presence of excess oxygen, the generation of $\mathrm{CO}_{2}$ is favored. Also, a possible reason for this effect could be the fact that blends of lignite with corn stover have a lower hydrogen content as seen in Table 2. This results in lower energy content material which burns or combusts readily in the presence of oxygen to emit more $\mathrm{CO}_{2}$ as compared to blends of sub-bituminous coal and corn stover. This result is also in accordance with the average $\mathrm{CO}_{2}$ emission factors supplied by U.S Energy Information Administration which states that anthracite emits the largest amount of $\mathrm{CO}_{2}$ followed by Lignite, SubBituminous and Bituminous [33, 34].

To support the fact that addition of corn stover to the coals affects the product gas compositions, the carbon isotope composition of the gaseous products $\mathrm{CO}$ and $\mathrm{CO}_{2}$ are plotted 
with respect to the amount of corn stover in the two feedstocks (Figures 2 and 3). With an increase in the amount of corn stover in the feed, gasification at a constant $\mathrm{O}_{2}$ : steam ratio results in a steady increase in the carbon isotope composition of the carbon containing gases, or the product gas becomes isotopically heavier during gasification. On the contrary, the isotope values for decreasing $\mathrm{O}_{2}$ :steam ratios at any constant corn stover percentage results in $\mathrm{CO}$ being enriched and $\mathrm{CO}_{2}$ being depleted in ${ }^{13} \mathrm{C}$. The implication is that carbon from both sources (coals and corn stover) is contributing in the generation of $\mathrm{CO}$ and $\mathrm{CO}_{2}$. Although all blends follow a similar trend, distinctions are observed in the isotopic signatures. For example, in blends of corn stover with sub-bituminous coal, the $\mathrm{CO}$ in the product gas is enriched in ${ }^{13} \mathrm{C}$ compared to pure coal by a maximum of about $6 \%$ whereas $\mathrm{CO}_{2}$ is only enriched by about $3 \%$ when $30 \%$ corn stover is added and gasified at an $\mathrm{O}_{2}$ :steam ratio of 0.5:1 while there is only an increase of about $4 \%$ in $\mathrm{CO}$ and $1 \%$ in $\mathrm{CO}_{2}$ when corn stover is blended with lignite and treated under similar conditions. This indicates that corn stover is more readily converted to $\mathrm{CO}$ in the presence of sub-bituminous coal than lignite coal at lower $\mathrm{O}_{2}$ :steam ratios. Although the gas composition data in Table 2 shows that the difference in the $\mathrm{CO}$ compositions are very little between the two coals, the isotope analysis provides better distinctions in comparing the interactions between corn stover and coals.

On the other hand, at higher $\mathrm{O}_{2}$ :steam ratio of $2: 1$, as an illustration, in blends of corn stover and sub-bituminous coal, $\mathrm{CO}_{2}$ is enriched in ${ }^{13} \mathrm{C}$ compared to pure coal by a maximum of $7 \%$ at an $\mathrm{O}_{2}$ :steam ratio of 2:1 (30\% corn stover blend) whereas $\mathrm{CO}$ is only enriched by $4 \%$, a decrease by about $2 \%$ when compared with lower $\mathrm{O}_{2}$ :steam ratio of $0.5: 1$. The isotope values of $\mathrm{CO}_{2}$ in blends of corn stover with sub-bituminous coal are slightly lower in $\delta{ }^{13} \mathrm{C}$ value (17.90 $\%$,-16.92 \%o,-16.73\%o) than $\mathrm{CO}_{2}$ generated from the blends with lignite coal $(-17.37 \%$, -16.19 
$\%,-15.24 \%$ ) at a $2: 1 \mathrm{O}_{2}$ :steam and corn stover percentages of 10,20 and $30 \%$ respectively. When compared, CS blends with each of the coals do not show much variation in $\delta{ }^{13} \mathrm{C}(\mathrm{CO})$ values even with change in $\mathrm{O}_{2} /$ steam ratio at lower percentages of corn stover, but the differences are clearly evident at higher loadings of corn stover. But, the same cannot be said for $\mathrm{CO}_{2}$ whose isotope value is enriched in ${ }^{13} \mathrm{C}$ with increasing $\mathrm{O}_{2}$ :steam ratio at any blend percentage of corn stover. This indicates that at higher $\mathrm{O}_{2}$ :steam ratios, corn stover is more readily converted to $\mathrm{CO}_{2}$ while most of the $\mathrm{CO}$ is generated via coal. The results shown in Table 4, thus indicate that corn stover is definitely contributing towards the generation of these gases and a probable interactions may be existing between the blended feedstock materials.

\subsection{Blends with Switchgrass}

As in the case of corn stover, blends of both coals with switchgrass follow similar trends in the generation of the carbonaceous gases although the $\mathrm{CO} / \mathrm{CO}_{2}$ ratios are much lower in blends with switchgrass implying higher carbon dioxide generation when compared with corn stover at any constant $\mathrm{O}_{2}$ :steam ratio or blend percentage (Table 2). The exact reason for this occurrence is speculative but the removal of higher percentage of volatile matter from switchgrass during pyrolysis may be resulting in char with higher void fraction due to which the interaction with incoming steam is reduced, thereby, generating more carbon dioxide through combustion in the bottom zone of the gasifier. The isotopic signature of the carbonaceous gases produced during the gasification of coal-switchgrass blends is shown in Figures 4 and 5. The results obtained show similar trends when compared with coal-corn stover blends, that is, the isotope values increase with increasing percentage of switchgrass in the feedstock at any constant $\mathrm{O}_{2} /$ steam ratio. An interesting observation is that, based on the isotope results, the affinity of switchgrass towards the production of $\mathrm{CO}$ increases with increasing $\mathrm{O}_{2}$ :steam ratio in 
the feed stream. The shift in isotope values is only about 1-1.5 \%o at lower switchgrass percentages (10\% and $20 \%$ ), whereas, the difference increases to about $5 \%$ when the switchgrass percentage in the blends is $30 \%$. This is contrary to the results obtained for corn stover where in the isotope values for $\mathrm{CO}$ increase at a constant rate with increasing steam concentration in the feed stream and the shift in isotope values is only about $1 \%$ even at higher percentages of corn stover. This may be due to the fact that switchgrass inherently has higher volatile content when compared to corn stover as shown in Table 1, which evolves at higher temperatures causing a shift in the isotopic abundance of $\mathrm{CO}$.

\subsection{Statistical Significance of Experimental Data}

Analysis of variance (ANOVA) was performed on the experimental results using Design Expert $^{\circledR} 9.0$ software to analyze the statistical significance of the data and also verify the effect of the treatment factors (\% Biomass and $\mathrm{O}_{2} /$ steam ratio) on the response variables $(\% \mathrm{CO}, \%$ $\mathrm{CO}_{2}, \mathrm{CO} / \mathrm{CO}_{2}$ ratio, $\delta^{13} \mathrm{C}(\mathrm{CO})$ and $\left.\delta^{13} \mathrm{C}\left(\mathrm{CO}_{2}\right)\right)$. The advantage of using ANOVA lies in the fact that multiple factors affecting a system's performance can be analyzed simultaneously using all the experimental data, rather than analyzing one factor at a time [35]. Typically, linear or quadratic equations are used for estimating the relationship between treatment factors and response variables while the coefficients are estimated using a least-squares fit of the experimental data. The p-value determines the probability of a particular case that the coefficient for a specific term does not have a significant effect. In other words, a small p-value (generally less than 0.05) indicates that the individual terms in the model have a significant effect on the response and p-values larger than 0.1 indicate that the specific term is insignificant and does not have any effect on the response. In Table 5, p-values are provided for the whole model and also for each specific term of the model used. These $\mathrm{p}$-values indicate that both the treatment factors 
have a significant effect on the percentage of $\mathrm{CO}$ generated during gasification of all the feedstocks (very low p-values $\ll 0.05$ ), but, the ratio of $\mathrm{O}_{2} /$ steam does not have a significant effect on the percentage of $\mathrm{CO}_{2}$ that is generated (p-values $>>0.05$ ). Similarly, very low p-

values $(<<0.05)$ have been obtained for the other response variables $\left(\mathrm{CO} / \mathrm{CO}_{2}, \delta^{13} \mathrm{C}(\mathrm{CO})\right.$ and $\left.\delta^{13} \mathrm{C}\left(\mathrm{CO}_{2}\right)\right)$ indicating that the desired output variables are significantly influenced by a change in the process variables. R-squared values obtained for different models have also been provided in Table 5. These values are close to 1 in most cases and thus, indicate a very good fit of the suggested models.

\subsection{Isotope Equilibrium}

The generation of $\mathrm{CO}$ and $\mathrm{CO}_{2}$ during gasification can therefore be explained via two possible theories (Tables 2 and 4). One possibility is that there might be an existence of a partial isotopic equilibrium between $\mathrm{CO}_{2}$ and $\mathrm{CO}$ according to the following isotope exchange reaction:

$$
{ }^{12} \mathrm{CO}_{2}+{ }^{13} \mathrm{CO} \leftrightarrow{ }^{13} \mathrm{CO}_{2}+{ }^{12} \mathrm{CO}
$$

These two gases, $\mathrm{CO}$ and $\mathrm{CO}_{2}$ could be produced in isotope equilibrium or they may form due to the gasification of solid carbon and re-equilibrate isotopically in the gasifier according to Equation 9. Using the observed $\delta^{13} \mathrm{C}$ values for $\mathrm{CO}_{2}$ and $\mathrm{CO}$ and the carbon isotope fractionation factor reported as a function of temperature by Richet et al [20, 36-38], apparent equilibrium temperatures (AET) for the isotope exchange reaction can be estimated. Based on the values of fractionation factor for $\mathrm{CO}-\mathrm{CO}_{2}$ isotope exchange provided by Richet et al.[36, 38], with an increase in temperature, the difference between the $\delta^{13} \mathrm{C}$ values of $\mathrm{CO}_{2}$ and $\mathrm{CO}$ decreases.

An increase in the $\mathrm{O}_{2}$ :steam ratio implies an increase in the gasification temperature. For blends of corn stover with both coals, only when the percentages of corn stover in the blend are 
lower $(10 \%$ and $20 \%)$ and high temperatures in excess of $1000{ }^{\circ} \mathrm{C}$ at an $\mathrm{O}_{2}$ :steam ratio of 2:1 are attained in the gasifier, there exists the potential for an isotopic equilibrium between $\mathrm{CO}$ and $\mathrm{CO}_{2}$ as the observed average gasifier temperatures are close to the calculated isotopic equilibrium temperatures (Table 6). For lower gasifier temperatures (i.e., lower $\mathrm{O}_{2}$ :steam ratios) and higher corn stover loadings (30\%), the calculated apparent equilibrium temperature deviates from the observed gasifier temperatures. Moreover, the difference in $\delta^{13} \mathrm{C}$ values between $\mathrm{CO}_{2}$ and $\mathrm{CO}$ increases with increasing temperatures which is opposite in direction to the expected trend of convergence in carbon isotope composition as temperature increases. Thus, an isotope exchange equilibrium does not exist.

The carbon isotope results may be explained by two chemical reactions: 1) Boudouard reaction (Equation 5) and 2) Water Gas Shift reaction (Equation 7). Boudouard reaction is endothermic by nature, therefore from thermodynamics, the formation of $\mathrm{CO}$ would result in a decrease in temperature of the gasification zone. This reduction in temperature would, therefore, favor the water gas shift reaction which is exothermic by nature and high conversions of $\mathrm{CO}$ and steam to $\mathrm{CO}_{2}$ and $\mathrm{H}_{2}$ can be obtained. From the product gas compositions shown in Table 2 and maximum gasifier temperatures shown in Table 6 , the ratio of $\mathrm{CO} / \mathrm{CO}_{2}$ decreases with decreasing temperature (decreasing $\mathrm{O}_{2}$ :steam ratios) for corn stover blends and therefore, the relationship between $\mathrm{CO}-\mathrm{CO}_{2}$ proceeds via the kinetic conversion of $\mathrm{CO}$ to $\mathrm{CO}_{2}$ and no isotope exchange is occurring between $\mathrm{CO}$ and $\mathrm{CO}_{2}$ in these chemical reactions.

A similar argument may be made for interpreting the carbon isotope composition of $\mathrm{CO}$ and $\mathrm{CO}_{2}$ in blends with switchgrass. As shown in Table 4 and Figures 4-5, although $\mathrm{CO}$ is enriched in ${ }^{13} \mathrm{C}$ with increasing temperature at a given percentage of switchgrass, and the variation in the $\delta^{13} \mathrm{C}$ values of $\mathrm{CO}_{2}$ is minimal (i.e., the difference in $\delta{ }^{13} \mathrm{C}$ values of $\mathrm{CO}_{2}$ and $\mathrm{CO}$ 
is decreasing with increasing temperatures), the calculated isotopic equilibrium temperatures from $\mathrm{CO}$ and $\mathrm{CO}_{2}$ are unreasonably high (Table 6). Also, the data from the product gas composition (Table 2) of the gasifier shows that the ratio of $\mathrm{CO} / \mathrm{CO}_{2}$ decreases with decreasing temperature which is in conjunction with the results obtained for corn stover blends. The calculated AETs for all sample blends are much higher than the actual gasifier temperatures and from Table 6, it is evident that the temperatures achieved in the gasifier are far from equilibrium and therefore, isotopic equilibrium is not achieved even with blends of switchgrass.

\subsection{Carbon Sourcing}

To interpret the amount of each parent source incorporated into the carbon containing gases, the following expression has been utilized:

$$
\left(\delta^{13} C X\right)_{\text {Biomass }}+\left(\delta^{13} C X\right) \quad \text { coal }=\delta^{13} C \quad \text { Product } \quad \text { (Equation 10) }
$$

And,

$$
X_{\text {Biomass }}+X_{\text {Coal }}=1
$$

Where, $\mathrm{X}$ is the fraction of parent material incorporated into product gas.

Therefore, $\quad\left(\%\right.$ Biomass Carbon $\left.=\frac{\delta^{13} C_{\text {Product }}-\delta^{13} C_{\text {Biomass }}}{\delta^{13} C_{\text {Biomass }}-\delta^{13} C_{\text {coal }}}\right)$

For this analysis, it is assumed that the $\delta^{13} \mathrm{C}$ values of the parental material and the gaseous products are equivalent over the course of the experiment, i.e., no isotope fractionation occurs during the reaction $[17,39]$. The contribution of each parent material in the generation of $\mathrm{CO}$ and $\mathrm{CO}_{2}$ is shown in Figure 6. The results of this analysis suggest that the contribution of biomass in the generation of both $\mathrm{CO}$ and $\mathrm{CO}_{2}$ is greater in blends with sub-bituminous coal as compared with blends of lignite. Using Equation 12, it can be clearly seen, that the addition of biomass has 
had a definite impact in the generation of carbon containing gases. If no interactions are present between biomass and coals, then the resultant product gas mixture would have isotope values that are closer to the source coal and enriched in ${ }^{12} \mathrm{C}$. As this is not occurring, it may be suggested that the synergy between corn stover and coals is higher at higher $\mathrm{O}_{2}$ :steam ratios (2:1), with corn stover contributing almost up to $60 \%$ and $70 \%$ with respect to the generation of $\mathrm{CO}_{2}$ in its blends with sub-bituminous coal and lignite respectively, while, the blends of switchgrass with coals contribute only about $45 \%$ at the same $\mathrm{O}_{2}$ :steam ratio (2:1). At lower $\mathrm{O}_{2}$ :steam ratios (0.5:1), however, the contribution of switchgrass ( $43 \%$ in blends with SB and 38 $\%$ in blends with LG) is higher than corn stover (36\% in blends with SB and $18 \%$ in blends with $\mathrm{LG}$ ) with respect to the generation $\mathrm{CO}_{2}$. Considering the generation of $\mathrm{CO}$, the contribution of corn stover is maximum at an $\mathrm{O}_{2}$ :steam ratio of 0.5:1 (40\% and $27 \%$ in blends with SB and LG respectively) while the contribution from switchgrass is maximum at a 2:1 ratio of $\mathrm{O}_{2}$ :steam (53\% and $41 \%$ in blends with SB and LG respectively). These comparisons are being made at $30 \%$ biomass blend ratios where the contribution of biomass towards the generation of $\mathrm{CO}$ and $\mathrm{CO}_{2}$ is the highest. These results are particularly important to know during co-gasification of coal/biomass blends as one of the major reasons for blending biomass with coal is to mitigate the emission of greenhouse gases. Moreover, the interpretation of these data would only help in process modeling and optimization of co-gasification processes. Ultimately, the usage of the data from this analysis depends on the end product one would like to achieve by heat treating or chemical conversion of coal/biomass blends.

\section{Conclusions}

An effective method has been utilized for analyzing and distinguishing the individual contributions of coal and biomass towards the generation of carbonaceous gases using the 
differences in their carbon isotope ratios. Corn stover and switchgrass were used as the biomass materials and were blended up to $30 \%$ by weight with two different ranks of coal, i.e., subbituminous and lignite. The gasification of these blends was performed at varying $\mathrm{O}_{2} /$ steam ratios in a moving bed gasifier and the generated carbon gases were effectively analyzed using stable carbon isotope ratio mass spectrometry. It was observed that an increase in the amount of biomass in the feed, led to a steady increase in the isotopic value of the carbon containing gases, implying that the product gas becomes isotopically heavier during gasification. This is also an indication of probable synergistic effects between the blended materials. Furthermore, the correlation between the $\delta^{13} \mathrm{C}$ values and gasifier temperatures suggests that $\mathrm{CO} / \mathrm{CO}_{2}$ ratio proceeds via a kinetic mechanism rather than an isotopic exchange. The amount of each parent material utilized for the generation of the product gases was calculated using a simple mixing equation. The addition of biomass had a definite impact in the generation of carbon containing gases. For blends with corn stover, higher $\mathrm{O}_{2}$ :steam ratios result in the contribution of almost up to $70 \%$ of carbon from corn stover in the generation of $\mathrm{CO}_{2}$, while, the blends of switchgrass with coals prove to be much effective at lower oxidant ratios with respect to the generation $\mathrm{CO}_{2}$ and vice versa for the generation of CO. Finally, it can be stated that the data obtained utilizing this unique analytical technique would provide valuable insights not only pertaining to the synergy between the blended feedstock materials but also towards process modeling, optimization and reaction pathways in the field of co-gasification of coal and biomass.

\section{Acknowledgement}

The authors would like to express their gratitude to the Department of Energy for funding this research and also to the Center for Applied Energy Research at the University of Kentucky for their timely support in providing the biomass samples. 


\section{References}

[1] P. Basu, Biomass Gasification and Pyrolysis: Practical Design and Theory, in, Elsevier Inc., 2010.

[2] R.C. Brown, Biorenewable Resources: Engineering New Products from Agriculture, 1 ed., Blackwell Publishing, 2003.

[3] R. Fernando, Co-gasification and indirect co-firing of coal and biomass, in: Profiles, IEA Clean Coal Centre, December, 2009, pp. 9-14.

[4] A. Singh, P. Singh, M. Singh, Biomethanization of coal to obtain clean coal energy: a review, Energy, Exploration \& Exploitation, 30 (2012) 837-852.

[5] Colomba Di Blasi, G. Signorelli, G. Portoricco, Countercurrent Fixed-Bed Gasification of Biomass at Laboratory Scale, Industrial and Engineering Chemistry Research, 38 (1999) 25712581.

[6] G. Gordillo, K. Annamalai, N. Carlin, Adiabatic fixed-bed gasification of coal, dairy biomass, and feedlot biomass using an air-steam mixture as an oxidizing agent, Renewable Energy, 34 (2009) 2789-2797.

[7] D.L. Klass, Biomass for Renewable Energy, Fuels, and Chemicals, Academic Press, San Diego, 1998.

[8] America's Energy Future Panel on Alternative Transportation Fuels, Liquid Transportation Fuels from Coal and Biomass: Technological Status, Costs, And Environmental Impacts., The National Academic Press, Washington, D.C., 2009.

[9] M.J. Prins, J.P. Krzysztof, F.J.J.G. Janssen, From Coal to Biomass Gasification: Comparison of Thermodynamic Efficiency., Energy, 32 (2007) 1248-1259. 
[10] A.J. Buczynska, B. Geypens, R. Van Grieken, K. De Wael, Stable carbon isotopic ratio measurement of polycyclic aromatic hydrocarbons as a tool for source identification and apportionment--a review of analytical methodologies, Talanta, 105 (2013) 435-450.

[11] D.E. Matthews, J.M. Hayes, Isotope-Ratio-Monitoring Gas Chromatography-Mass Spectrometry, Anal Chem, 50 (1978) 1465-1473.

[12] T. Okuda, H. Kumata, H. Naraoka, H. Takada, Origin of atmospheric polycyclic aromatic hydrocarbons (PAHs) in Chinese cities solved by compound-specific stable carbon isotopic analyses, Org Geochem, 33 (2002) 1737-1745.

[13] C. McRae, C.-G. Sun, C.E. Snape, A.E. Fallick, D. Taylor, $\delta^{13}$ C values of coal-derived PAHs from different processes and their application to source apportionment, Org Geochem, 30 (1999) 881-889.

[14] S.H. Bottrell, P.K.K. Louie, K.D. Bartle, N. Taylor, S. Wallace, W. Kemp, W. Steedman, Differentiation of Forward and Back Reactions during Co-Processing of Coal and Petroleum by Isotope Mass Balance Analysis, Fuel, 69 (1990) 1332-1333.

[15] M.S. Lancet, R.A. Winschel, F.P. Burke, Stable Carbon Isotope Analysis of Coprocessing Materials, Abstr Pap Am Chem S, 202 (1991) 71.

[16] M.S. Lancet, R.A. Winschel, F.P. Burke, Stable Carbon-Isotope Analysis of Coprocessing Materials, Fuel, 72 (1993) 1209-1217.

[17] J.G. Steer, T. Ohuchi, K. Muehlenbachs, Efficacy of Coal-Bitumen Co-Processing as Determined by Isotopic Mass Balance Calculations, Fuel Process Technol, 15 (1987) 429-438.

[18] H. Craig, Isotopic Standards for Carbon and Oxygen and Correction Factors for MassSpectrometric Analysis of Carbon Dioxide, Geochim Cosmochim Ac, 12 (1957) 133-149. 
[19] J. Hoefs, E. Usdowski, C-13/C-12 Fractionation and Kinetics of $\mathrm{CO}_{2}$ Absorption by Hydroxide Solutions, Fortschr Mineral, 65 (1987) 76-76.

[20] A. Brasseur, D. Antenucci, J.-M. Bouquegneau, A. Coëme, P. Dauby, R. Létolle, M. Mostade, P. Pirlot, J.-P. Pirard, Carbon stable isotope analysis as a tool for tracing temperature during the El Tremedal underground coal gasification at great depth, Fuel, 81 (2002) 109-117. [21] P.K. Singh, M.P. Singh, P.K. Prachiti, M.S. Kalpana, C. Manikyamba, G. Lakshminarayana, A.K. Singh, A.S. Naik, Petrographic characteristics and carbon isotopic composition of Permian coal: Implications on depositional environment of Sattupalli coalfield, Godavari Valley, India, International Journal of Coal Geology, 90-91 (2012) 34-42.

[22] S.A. Robinson, S.P. Hesselbo, Fossil-wood carbon-isotope stratigraphy of the non-marine Wealden group (Lower cretaceous, southern england), J Geol Soc London, 161 (2004) 133-145.

[23] R.F. Follett, K.P. Vogel, G.E. Varvel, R.B. Mitchell, J. Kimble, Soil Carbon Sequestration by Switchgrass and No-Till Maize Grown for Bioenergy, Bioenerg Res, 5 (2012) 866-875.

[24] A. Bechtel, R. Gratzer, R.F. Sachsenhofer, J. Gusterhuber, A. Lucke, W. Puttmann, Biomarker and carbon isotope variation in coal and fossil wood of Central Europe through the Cenozoic, Palaeogeogr Palaeocl, 262 (2008) 166-175.

[25] M.J. Whiticar, Stable isotope geochemistry of coals, humic kerogens and related natural gases, International Journal of Coal Geology, 32 (1996) 191-215.

[26] K.M. Thomas, F. Dillon, S. Bottrell, P.K.K. Louie, K.D. Bartle, The Use of C-13/C-12 Isotope Mass-Spectrometry in the Study of the Gasification of Carbon Composite-Materials, Carbon, 31 (1993) 273-277.

[27] R.A. Winschel, F.P. Burke, M.S. Lancet, Application of Stable Carbon Isotope Analysis to Continuous Coal Oil Coprocessing, Abstr Pap Am Chem S, 200 (1990) 62. 
[28] Introduction Department of Energy Coal Sample Bank \& Database in: http://www.energy.psu.edu/copl/doesb.html.

[29] ASTM Standard D7582-12, "Standard Test Methods for Proximate Analysis of Coal and Coke by Macro Thermogravimetric Analysis", in, ASTM International, West Conshohocken, PA, 2013.

[30] ASTM Standard D5373-08, "Standard Test Methods for Determination of Carbon, Hydrogen and Nitrogen in Analysis Samples of Coal and Carbon in Analysis Samples of Coal and Coke", in, ASTM International, West Conshohocken, PA, 2013.

[31] ASTM Standard D4239-12, "Standard Test Method for Sulfur in the Analysis Sample of Coal and Coke Using High-Temperature Tube Furnace Combustion", in, ASTM International, West Conshohocken, PA, 2013.

[32] A. Dufaux, B. Gaveau, R. Létolle, M. Mostade, M. Noël, J.-P. Pirard, Heavy water tracing test in the underground coal gasification process at Thulin, Fuel, 69 (1990) 1454-1456.

[33] J.C. Quick, Carbon Dioxide Emission Factors for US Coal by Origin and Destination, Environ Sci Technol, 44 (2010) 2709-2714.

[34] B.D. Hong, E.R. Slatick, Carbon Dioxide Emission Factors for Coal in: Energy Information Administration, Quarterly Coal Report,, Washington, DC, August 1994, 1994, pp. 18.

[35] S. Karimipour, R. Gerspacher, R. Gupta, R.J. Spiteri, Study of factors affecting syngas quality and their interactions in fluidized bed gasification of lignite coal, Fuel, 103 (2013) 308320. 
[36] P. Richet, Y. Bottinga, M. Javoy, Review of Hydrogen, Carbon, Nitrogen, Oxygen, Sulfur, and Chlorine Stable Isotope Fractionation among Gaseous Molecules, Annu Rev Earth PI Sc, 5 (1977) 65-110.

[37] M. Sato, T. Mori, Y. Shimoike, K. Nagao, K. Notsu, Carbon isotope systematics of $\mathrm{CO}_{2}$, $\mathrm{CO}$ and $\mathrm{CH}_{4}$ in fumarolic gases from Satsuma-Iwojima volcanic island, Japan, Earth Planets Space, 54 (2002) 257-263.

[38] Y. Bottinga, Calculated fractionation factors for carbon and hydrogen isotope exchange in the system calcite-carbondioxide-graphite-methane-hydrogen-water vapor Geochim Cosmochim Ac, 33 (1969) 49-64.

[39] M. Schoell, The Hydrogen and Carbon Isotopic Composition of Methane from Natural Gases of Various Origins, Geochim Cosmochim Ac, 44 (1980) 649-661. 


\section{Figure Captions}

Figure 1: Schematic of the Laboratory Scale Moving Bed Gasification System for Gasifying Mixtures of Coal and Biomass.

Figure 2: Effect of increasing percentage of corn stover and varying oxygen/steam ratios on the isotopic signatures of product gases in its blends with DECS-38 sub-bituminous coal. (A) Isotopic Signature of CO, (B) Isotopic Signature of $\mathrm{CO}_{2}$.

Figure 3: Effect of increasing percentage of corn stover and varying oxygen/steam ratios on the isotopic signatures of product gases in its blends with DECS-25 lignite coal. (A) Isotopic Signature of $\mathrm{CO}$, (B) Isotopic Signature of $\mathrm{CO}_{2}$.

Figure 4: Effect of increasing percentage of switchgrass and varying oxygen/steam ratios on the isotopic signatures of product gases in its blends with DECS-38 sub-bituminous coal. (A) Isotopic Signature of $\mathrm{CO},(\mathrm{B})$ Isotopic Signature of $\mathrm{CO}_{2}$.

Figure 5: Effect of increasing percentage of switchgrass and varying oxygen/steam ratios on the isotopic signatures of product gases in its blends with DECS-25 lignite coal. (A) Isotopic Signature of CO, (B) Isotopic Signature of $\mathrm{CO}_{2}$.

Figure 6: Individual contribution of each biomass source towards generation of product gases at different $\mathrm{O}_{2} /$ steam ratios. (A) Contribution in the generation of CO in blends with DECS-38 subbituminous coal, (B) Contribution in the generation of $\mathrm{CO}_{2}$ in blends with DECS-38 subbituminous coal, (C) Contribution in the generation of CO in blends with DECS-25 lignite coal, and (D) Contribution in the generation of $\mathrm{CO}_{2}$ in blends with DECS-25 lignite coal. 


\section{Table Captions}

Table 1: Proximate and Elemental Analysis of Feedstocks Used for Gasification.

Table 2: Product Gas Compositions for $\mathrm{CO}$ and $\mathrm{CO}_{2}$ Produced During the Gasification of Various Coal/Biomass Blends at Different $\mathrm{O}_{2} /$ Steam Ratios.

Table 3: $\delta^{13} \mathrm{C}$ values of various feedstock materials.

Table 4: Carbon Isotope Ratios for $\mathrm{CO}$ and $\mathrm{CO}_{2}$ Produced During the Gasification of Various Coal/Biomass Blends at Different $\mathrm{O}_{2} /$ Steam Ratios.

Table 5: Analysis of Variance (ANOVA) for Models Generated Based on Experimental Data and Estimating the Statistical Significance (P-Values) Between Treatment Factors and Response Variables.

Table 6: Comparison of Isotopic Equilibrium Temperatures of $\mathrm{CO}_{2}-\mathrm{CO}$ Product Gases and Experimental Gasifier Temperatures. 
Table 1: Proximate and Elemental Analysis of Feedstocks Used for Gasification

\begin{tabular}{|c|c|c|c|c|c|c|c|c|c|}
\hline \multirow{2}{*}{ Feedstock } & \multicolumn{4}{|c|}{$\begin{array}{c}\text { Proximate Analysis } \\
\text { As Received Basis) }\end{array}$} & \multicolumn{5}{c|}{$\begin{array}{c}\text { Elemental Analysis } \\
\text { (As Received Basis) }\end{array}$} \\
\hline & $\begin{array}{c}\text { \% } \\
\text { Moisture }\end{array}$ & $\begin{array}{c}\text { \% Fixed } \\
\text { Carbon }\end{array}$ & $\begin{array}{c}\text { \% } \\
\text { Volatile } \\
\text { Matter }\end{array}$ & $\begin{array}{c}\text { \% } \\
\text { Ash }\end{array}$ & $\%$ C & \% H & \% N & \% S & \% \\
\hline $\begin{array}{c}\text { DECS-38 } \\
\text { Sub-Bituminous Coal }\end{array}$ & 22.01 & 39.66 & 34.58 & 3.75 & 56.82 & 3.95 & 0.98 & 0.44 & 12.36 \\
\hline $\begin{array}{c}\text { DECS-25 Lignite Coal } \\
\text { Dern Stover }\end{array}$ & 34.91 & 27.32 & 30.05 & 7.71 & 42.80 & 2.99 & 0.61 & 0.47 & 10.50 \\
\hline Switchgrass & 4.87 & 9.35 & 83.62 & 2.16 & 45.76 & 8.09 & 0.32 & 0.08 & 42.87 \\
\hline
\end{tabular}


Table 2: Product Gas Compositions for $\mathrm{CO}$ and $\mathrm{CO}_{2}$ Produced During the Gasification of Various Coal/Biomass Blends at Different $\mathrm{O}_{2} /$ Steam Ratios

\begin{tabular}{|c|c|c|c|c|c|c|c|c|c|c|c|c|c|}
\hline \multirow{2}{*}{\multicolumn{2}{|c|}{\begin{tabular}{|c|} 
Operating \\
Conditions \\
$\mathrm{O}_{2}:$ Steam \\
\end{tabular}}} & \multicolumn{12}{|c|}{ Average Gasifier Product Gas Composition, \% ( $\sigma$ values calculated for $n=5)$} \\
\hline & & \multicolumn{6}{|c|}{ Pure SB } & \multicolumn{6}{|c|}{ Pure LG } \\
\hline & & \multicolumn{2}{|c|}{$\operatorname{CO}(\sigma)$} & \multicolumn{2}{|c|}{$\mathrm{CO}_{2}(\sigma)$} & \multicolumn{2}{|c|}{$\mathrm{CO} / \mathrm{CO}_{2}$} & \multicolumn{2}{|c|}{$\mathrm{CO}(\sigma)$} & \multicolumn{2}{|c|}{$\mathrm{CO}_{2}(\sigma)$} & \multicolumn{2}{|c|}{$\mathrm{CO} / \mathrm{CO}_{2}$} \\
\hline \multicolumn{2}{|c|}{2.0} & \multicolumn{2}{|c|}{$31.27 \%(1.51)$} & \multicolumn{2}{|c|}{$41.69 \%(1.24)$} & \multicolumn{2}{|c|}{0.75} & \multicolumn{2}{|c|}{$34.43 \%(2.02)$} & \multicolumn{2}{|c|}{$46.37 \%(1.15)$} & \multicolumn{2}{|c|}{0.74} \\
\hline \multicolumn{2}{|c|}{1.0} & \multicolumn{2}{|c|}{$26.13 \%(1.13)$} & \multicolumn{2}{|c|}{$41.68 \%(1.33)$} & \multicolumn{2}{|c|}{0.63} & \multicolumn{2}{|c|}{$27.58 \%(1.93)$} & \multicolumn{2}{|c|}{$45.47 \%(1.29)$} & \multicolumn{2}{|c|}{0.61} \\
\hline \multicolumn{2}{|c|}{0.5} & \multicolumn{2}{|c|}{$21.63 \%(1.28)$} & \multicolumn{2}{|c|}{$42.66 \%(1.41)$} & \multicolumn{2}{|c|}{0.51} & \multicolumn{2}{|c|}{$22.03 \%(1.58)$} & \multicolumn{2}{|c|}{$45.90 \%(1.17)$} & \multicolumn{2}{|c|}{0.48} \\
\hline O.Steam & Biomass & & $\mathrm{SB}+\mathrm{C}$ & & & $\mathbf{S B}+\mathbf{S C}$ & & & $\mathbf{L G}+\mathbf{C}$ & & & $\mathbf{L G}+\mathbf{S G}$ & \\
\hline $0_{2} \cdot$ Stean & Wt \% & CO & $\mathrm{CO}_{2}$ & $\mathrm{CO} / \mathrm{CO}_{2}$ & $\mathrm{CO}$ & $\mathrm{CO}_{2}$ & $\mathrm{CO} / \mathrm{CO}_{2}$ & $\mathbf{C O}$ & $\mathrm{CO}_{2}$ & $\mathrm{CO} / \mathrm{CO}_{2}$ & $\mathrm{CO}$ & $\mathrm{CO}_{2}$ & $\mathrm{CO} / \mathrm{CO}_{2}$ \\
\hline 2.0 & & $31.94 \%$ & $43.29 \%$ & 0.74 & $28.91 \%$ & $45.86 \%$ & 0.63 & $32.18 \%$ & $46.45 \%$ & 0.69 & $30.05 \%$ & $53.65 \%$ & 0.56 \\
\hline 1.0 & & $26.58 \%$ & $43.69 \%$ & 0.61 & $24.35 \%$ & $46.02 \%$ & 0.53 & $27.20 \%$ & $46.20 \%$ & 0.59 & $24.41 \%$ & $52.58 \%$ & 0.46 \\
\hline 0.5 & & $22.17 \%$ & $43.13 \%$ & 0.51 & $22.83 \%$ & $46.62 \%$ & 0.49 & $21.64 \%$ & $46.05 \%$ & 0.49 & $22.38 \%$ & $52.07 \%$ & 0.43 \\
\hline & $10 \%$ & $\sigma(\mathrm{CO})$ & & $\left(\mathrm{CO}_{2}\right)$ & $\sigma(\mathrm{C}$ & & $\sigma\left(\mathrm{CO}_{2}\right)$ & $\sigma(\mathrm{CC}$ & & $\sigma\left(\mathrm{CO}_{2}\right)$ & $\sigma(\mathrm{C}$ & & $\sigma\left(\mathrm{CO}_{2}\right)$ \\
\hline 2.0 & & $1.09 \%$ & & $.15 \%$ & 1.38 & & $2.18 \%$ & $1.65 \%$ & & $1.98 \%$ & 1.61 & & $2.32 \%$ \\
\hline 1.0 & & $1.71 \%$ & & $.24 \%$ & $2.11^{c}$ & & $2.27 \%$ & 2.019 & & $1.43 \%$ & 1.88 & & $1.76 \%$ \\
\hline 0.5 & & $1.13 \%$ & & $.78 \%$ & 1.93 & & $2.82 \%$ & $2.23 \%$ & & $2.07 \%$ & 1.72 & & $1.91 \%$ \\
\hline 2.0 & & $25.34 \%$ & $48.17 \%$ & 0.53 & $19.72 \%$ & $53.68 \%$ & 0.37 & $23.93 \%$ & $51.12 \%$ & 0.47 & $19.05 \%$ & $63.23 \%$ & 0.30 \\
\hline 1.0 & & $22.56 \%$ & $47.43 \%$ & 0.48 & $16.45 \%$ & $53.11 \%$ & 0.32 & $20.68 \%$ & $50.94 \%$ & 0.40 & $15.34 \%$ & $64.18 \%$ & 0.24 \\
\hline 0.5 & & $20.11 \%$ & $47.11 \%$ & 0.43 & $14.88 \%$ & $53.57 \%$ & 0.28 & $18.14 \%$ & $51.74 \%$ & 0.35 & $12.74 \%$ & $64.06 \%$ & 0.20 \\
\hline & $20 \%$ & $\sigma(\mathrm{CO})$ & & $\left(\mathrm{CO}_{2}\right)$ & $\sigma(\mathrm{C}$ & & $\sigma\left(\mathrm{CO}_{2}\right)$ & $\sigma(\mathrm{CC}$ & & $\sigma\left(\mathrm{CO}_{2}\right)$ & $\sigma(\mathrm{C}$ & & $\sigma\left(\mathrm{CO}_{2}\right)$ \\
\hline 2.0 & & 2.02 & & 1.26 & 1.99 & & 2.29 & 2.10 & & 1.23 & 2.6 & & 2.07 \\
\hline 1.0 & & 1.78 & & 1.69 & 2.52 & & 1.98 & 2.79 & & 1.95 & 2.4 & & 1.64 \\
\hline 0.5 & & 1.91 & & 1.17 & 1.44 & & 1.26 & 2.59 & & 1.47 & 2.5 & & 1.92 \\
\hline
\end{tabular}




\begin{tabular}{|c|c|c|c|c|c|c|c|c|c|c|c|c|c|}
\hline \multirow{2}{*}{$\mathrm{O}_{2}:$ Steam } & \multirow{2}{*}{$\begin{array}{c}\text { Biomass } \\
\text { Wt \% }\end{array}$} & \multicolumn{3}{|c|}{$\mathrm{SB}+\mathrm{CS}$} & \multicolumn{3}{|c|}{$\mathrm{SB}+\mathrm{SG}$} & \multicolumn{3}{|c|}{$\mathbf{L G}+\mathbf{C S}$} & \multicolumn{3}{|c|}{$\mathbf{L G}+\mathbf{S G}$} \\
\hline & & $\mathrm{CO}$ & $\mathrm{CO}_{2}$ & $\mathrm{CO} / \mathrm{CO}_{2}$ & $\mathrm{CO}$ & $\mathrm{CO}_{2}$ & $\mathrm{CO} / \mathrm{CO}_{2}$ & $\mathrm{CO}$ & $\mathrm{CO}_{2}$ & $\mathrm{CO} / \mathrm{CO}_{2}$ & $\mathrm{CO}$ & $\mathrm{CO}_{2}$ & $\mathrm{CO} / \mathrm{CO}_{2}$ \\
\hline 2.0 & \multirow{7}{*}{$30 \%$} & $18.13 \%$ & $56.67 \%$ & 0.32 & $16.00 \%$ & $62.52 \%$ & 0.26 & $17.14 \%$ & $60.93 \%$ & 0.28 & $14.34 \%$ & $69.80 \%$ & 0.21 \\
\hline 1.0 & & $15.73 \%$ & $56.79 \%$ & 0.28 & $14.50 \%$ & $62.03 \%$ & 0.23 & $15.14 \%$ & $61.17 \%$ & 0.25 & $12.81 \%$ & $70.94 \%$ & 0.18 \\
\hline \multirow[t]{2}{*}{0.5} & & $13.09 \%$ & $56.17 \%$ & 0.23 & $10.02 \%$ & $63.43 \%$ & 0.16 & $12.39 \%$ & $61.11 \%$ & 0.20 & $11.69 \%$ & $70.14 \%$ & 0.16 \\
\hline & & \multicolumn{2}{|l|}{$\sigma(\mathrm{CO})$} & $\sigma\left(\mathrm{CO}_{2}\right)$ & \multicolumn{2}{|c|}{$\sigma(\mathrm{CO})$} & $\sigma\left(\mathrm{CO}_{2}\right)$ & \multicolumn{2}{|c|}{$\sigma(\mathrm{CO})$} & $\sigma\left(\mathrm{CO}_{2}\right)$ & \multicolumn{2}{|c|}{$\sigma(\mathrm{CO})$} & $\sigma\left(\mathrm{CO}_{2}\right)$ \\
\hline 2.0 & & \multicolumn{2}{|l|}{2.14} & 2.29 & \multicolumn{2}{|c|}{2.87} & 1.93 & \multicolumn{2}{|c|}{1.29} & 1.97 & \multicolumn{2}{|c|}{2.10} & 1.93 \\
\hline 1.0 & & \multicolumn{2}{|l|}{2.08} & 1.98 & \multicolumn{2}{|c|}{2.61} & 2.18 & \multicolumn{2}{|l|}{1.85} & 1.38 & \multicolumn{2}{|c|}{1.72} & 1.77 \\
\hline 0.5 & & \multicolumn{2}{|l|}{1.92} & 1.26 & \multicolumn{2}{|c|}{2.06} & 2.22 & \multicolumn{2}{|c|}{2.27} & 2.11 & \multicolumn{2}{|c|}{1.66} & 2.03 \\
\hline
\end{tabular}


Table 3: $\delta{ }^{13} \mathrm{C}$ values of various feedstock materials

\begin{tabular}{|c|c|}
\hline Feedstock & $\boldsymbol{\delta}^{\mathbf{1 3}} \mathbf{C ,} \mathbf{\% o}$ \\
\hline DECS-38 Sub-bituminous Coal & -25.31 \\
\hline DECS-25 Lignite Coal & -24.71 \\
\hline Corn Stover & -11.05 \\
\hline Switchgrass & -11.13 \\
\hline Pine & -24.62 \\
\hline Poplar & -23.93 \\
\hline
\end{tabular}


Table 4: Carbon Isotope Ratios for $\mathrm{CO}$ and $\mathrm{CO}_{2}$ Produced During the Gasification of Various Coal/Biomass Blends at Different $\mathrm{O}_{2}$ /Steam Ratios

\begin{tabular}{|c|c|c|c|c|c|c|c|c|c|c|c|c|c|c|c|c|c|}
\hline $\mathbf{O}_{2} / \mathbf{S t}$ & $\begin{array}{c}\text { Biomass } \\
\text { Wt } \%\end{array}$ & \multicolumn{16}{|c|}{$\delta{ }^{13} \mathrm{C}, \%$ ( $\sigma$ values calculated for $\left.n=5\right)$} \\
\hline \multirow{5}{*}{-} & \multirow{5}{*}{$0 \%$} & \multicolumn{8}{|c|}{ Pure SB } & \multicolumn{8}{|c|}{ Pure LG } \\
\hline & & \multicolumn{2}{|c|}{$\mathrm{CO}$} & \multicolumn{2}{|c|}{ St. Dev (б) } & \multicolumn{2}{|c|}{$\mathrm{CO}_{2}$} & \multicolumn{2}{|c|}{ St. Dev (o) } & \multicolumn{2}{|c|}{$\mathrm{CO}$} & \multicolumn{2}{|c|}{ St. Dev ( $\sigma)$} & \multicolumn{2}{|c|}{$\mathrm{CO}_{2}$} & \multicolumn{2}{|c|}{ St. Dev ( $\sigma)$} \\
\hline & & \multicolumn{2}{|c|}{-25.36} & \multicolumn{2}{|c|}{0.11} & \multicolumn{2}{|c|}{-23.46} & \multicolumn{2}{|c|}{0.21} & \multicolumn{2}{|c|}{-24.75} & \multicolumn{2}{|c|}{0.17} & \multicolumn{2}{|c|}{-23.26} & \multicolumn{2}{|c|}{0.19} \\
\hline & & \multicolumn{4}{|c|}{$\mathrm{SB}+\mathrm{CS}$} & \multicolumn{4}{|c|}{$\mathrm{SB}+\mathrm{SG}$} & \multicolumn{4}{|c|}{$\mathbf{L G}+\mathbf{C S}$} & \multicolumn{4}{|c|}{$\mathbf{L G}+\mathbf{S G}$} \\
\hline & & $\mathrm{CO}$ & $(\sigma)$ & $\mathrm{CO}_{2}$ & $(\sigma)$ & $\mathrm{CO}$ & $(\sigma)$ & $\mathrm{CO}_{2}$ & $(\sigma)$ & $\mathrm{CO}$ & $(\sigma)$ & $\mathrm{CO}_{2}$ & $(\sigma)$ & $\mathrm{CO}$ & $(\sigma)$ & $\mathrm{CO}_{2}$ & $(\sigma)$ \\
\hline 2.0 & \multirow{3}{*}{$10 \%$} & -24.47 & 0.15 & -17.90 & 0.14 & -22.59 & 0.09 & -20.91 & 0.08 & -24.61 & 0.07 & -17.37 & 0.07 & -23.58 & 0.13 & -20.85 & 0.05 \\
\hline 1.0 & & -24.04 & 0.11 & -20.51 & 0.07 & -23.02 & 0.13 & -21.11 & 0.17 & -24.38 & 0.04 & -22.23 & 0.14 & -24.21 & 0.09 & -21.13 & 0.06 \\
\hline 0.5 & & -23.91 & 0.18 & -21.04 & 0.20 & -23.38 & 0.12 & -21.35 & 0.05 & -24.06 & 0.06 & -23.96 & 0.04 & -24.52 & 0.11 & -21.28 & 0.12 \\
\hline 2.0 & \multirow{3}{*}{$20 \%$} & -23.47 & 0.16 & -16.92 & 0.18 & -20.35 & 0.09 & -20.19 & 0.05 & -23.72 & 0.10 & -16.19 & 0.09 & -22.49 & 0.07 & -19.74 & 0.08 \\
\hline 1.0 & & -22.34 & 0.08 & -19.51 & 0.09 & -21.78 & 0.06 & -20.49 & 0.04 & -23.42 & 0.19 & -20.81 & 0.20 & -24.00 & 0.10 & -20.13 & 0.09 \\
\hline 0.5 & & -21.26 & 0.16 & -20.38 & 0.09 & -22.81 & 0.13 & -20.65 & 0.13 & -23.23 & 0.15 & -22.74 & 0.06 & -24.40 & 0.04 & -20.34 & 0.07 \\
\hline 2.0 & \multirow{3}{*}{$30 \%$} & -21.56 & 0.22 & -16.73 & 0.13 & -17.84 & 0.14 & -18.90 & 0.04 & -22.43 & 0.14 & -15.24 & 0.02 & -19.16 & 0.12 & -18.44 & 0.05 \\
\hline 1.0 & & -20.72 & 0.12 & -18.97 & 0.06 & -20.43 & 0.09 & -19.15 & 0.08 & -21.88 & 0.09 & -17.96 & 0.09 & -22.89 & 0.06 & -19.07 & 0.11 \\
\hline 0.5 & & -19.54 & 0.17 & -20.17 & 0.06 & -22.10 & 17 & -19.26 & 0.05 & -20.99 & 0.05 & -22.28 & 0.02 & -23.88 & 0.08 & -19.54 & 0.07 \\
\hline
\end{tabular}


Table 5: Analysis of Variance (ANOVA) for Models Generated Based on Experimental Data and Estimating the Statistical

Significance (P-Values) Between Treatment Factors and Response Variables.

\begin{tabular}{|c|c|c|c|c|c|c|c|c|c|c|c|}
\hline \multirow{3}{*}{ Feedstock } & \multirow{3}{*}{$\begin{array}{c}\text { Treatment } \\
\text { Factors }\end{array}$} & \multicolumn{10}{|c|}{ Response Variables } \\
\hline & & \multicolumn{2}{|c|}{$\% \mathrm{CO}$} & \multicolumn{2}{|c|}{$\% \mathrm{CO}_{2}$} & \multicolumn{2}{|c|}{$\mathrm{CO} / \mathrm{CO}_{2}$} & \multicolumn{2}{|c|}{$\delta^{13} \mathrm{C}(\mathrm{CO})$} & \multicolumn{2}{|c|}{$\delta^{13} \mathrm{C}\left(\mathrm{CO}_{2}\right)$} \\
\hline & & \multicolumn{2}{|c|}{ P-Value } & \multicolumn{2}{|c|}{ P-Value } & \multicolumn{2}{|c|}{ P-Value } & \multicolumn{2}{|c|}{ P-Value } & \multicolumn{2}{|c|}{ P-Value } \\
\hline \multirow{7}{*}{$\mathbf{S B}+\mathbf{C S}$} & $\begin{array}{c}\text { Suggested } \\
\text { Model }\end{array}$ & Quadratic & $\begin{array}{c}< \\
0.0001 \\
\end{array}$ & Quadratic & $\begin{array}{c}< \\
0.0001 \\
\end{array}$ & Quadratic & $<0.0001$ & $2 \mathrm{FI}$ & $\begin{array}{c}< \\
0.0001 \\
\end{array}$ & Quadratic & $\begin{array}{c}< \\
0.0001 \\
\end{array}$ \\
\hline & $\mathrm{A}-\% \mathrm{CS}$ & \multicolumn{2}{|c|}{$<0.0001$} & \multicolumn{2}{|c|}{$<0.0001$} & \multicolumn{2}{|c|}{$<0.0001$} & \multicolumn{2}{|c|}{$<0.0001$} & \multicolumn{2}{|c|}{$<0.0001$} \\
\hline & $\mathrm{B}-\mathrm{O}_{2} /$ Steam & \multicolumn{2}{|c|}{$<0.0001$} & \multicolumn{2}{|c|}{0.7596} & \multicolumn{2}{|c|}{$<0.0001$} & \multicolumn{2}{|c|}{0.0003} & \multicolumn{2}{|c|}{0.0008} \\
\hline & $\mathbf{A B}$ & \multicolumn{2}{|c|}{0.0014} & \multicolumn{2}{|c|}{0.0802} & \multicolumn{2}{|c|}{0.0009} & \multicolumn{2}{|c|}{0.0015} & \multicolumn{2}{|c|}{0.0132} \\
\hline & $\mathbf{A}^{2}$ & \multicolumn{2}{|c|}{$<0.0001$} & \multicolumn{2}{|c|}{$<0.0001$} & \multicolumn{2}{|c|}{$<0.0001$} & \multicolumn{2}{|c|}{-} & \multicolumn{2}{|c|}{0.0018} \\
\hline & $\mathbf{B}^{2}$ & \multicolumn{2}{|c|}{0.0348} & 0.76 & & 0.06 & & & & 0.7 & \\
\hline & R-Squared & 0.99 & & 0.99 & & 0.99 & & & & 0.9 & \\
\hline & $\begin{array}{c}\text { Suggested } \\
\text { Model }\end{array}$ & Quadratic & $\begin{array}{c}< \\
0.0001 \\
\end{array}$ & Quadratic & $\begin{array}{c}< \\
0.0001 \\
\end{array}$ & Quadratic & $<0.0001$ & Linear & 0.0002 & Linear & $<0.0001$ \\
\hline & $\mathrm{A}-\% \mathrm{CS}$ & $<0.0$ & 001 & $<0.0$ & & $<0.0$ & 001 & $<0$ & & 0.0 & \\
\hline & $\mathrm{B}-\mathrm{O}_{2} /$ Steam & $<0.0$ & 001 & 0.72 & & $<0.0$ & 001 & & & $<0$. & 01 \\
\hline $\mathbf{L G}+\mathbf{C S}$ & $\mathbf{A B}$ & 0.00 & & 0.12 & & 0.00 & & & & 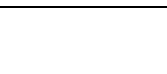 & \\
\hline & $\mathbf{A}^{2}$ & 0.00 & & $<0.0$ & 001 & 0.00 & & & & . & \\
\hline & $\mathbf{B}^{2}$ & 0.04 & & 0.91 & & 0.13 & & & & . & \\
\hline & R-Squared & 0.98 & & 0.99 & & 0.98 & & & & 0.9 & \\
\hline
\end{tabular}




\begin{tabular}{|c|c|c|c|c|c|c|c|c|c|c|c|}
\hline \multirow{3}{*}{ Feedstock } & \multirow{3}{*}{$\begin{array}{c}\text { Treatment } \\
\text { Factors }\end{array}$} & \multicolumn{10}{|c|}{ Response Variables } \\
\hline & & \multicolumn{2}{|c|}{$\% \mathrm{CO}$} & \multicolumn{2}{|c|}{$\% \mathrm{CO}_{2}$} & \multicolumn{2}{|c|}{$\mathrm{CO} / \mathrm{CO}_{2}$} & \multicolumn{2}{|c|}{$\delta^{13} \mathrm{C}(\mathrm{CO})$} & \multicolumn{2}{|c|}{$\delta^{13} \mathrm{C}\left(\mathrm{CO}_{2}\right)$} \\
\hline & & \multicolumn{2}{|c|}{ P-Value } & \multicolumn{2}{|c|}{ P-Value } & \multicolumn{2}{|c|}{ P-Value } & \multicolumn{2}{|c|}{ P-Value } & \multicolumn{2}{|c|}{ P-Value } \\
\hline \multirow{7}{*}{$\mathbf{S B}+\mathbf{S G}$} & $\begin{array}{c}\text { Suggested } \\
\text { Model }\end{array}$ & Linear & $\begin{array}{c}< \\
0.0001 \\
\end{array}$ & Quadratic & $\begin{array}{c}< \\
0.0001\end{array}$ & Linear & $<0.0451$ & Quadratic & $\begin{array}{c}< \\
0.0001\end{array}$ & Quadratic & $<0.0001$ \\
\hline & A - \% SG & \multicolumn{2}{|c|}{$<0.0001$} & \multicolumn{2}{|c|}{$<0.0001$} & \multicolumn{2}{|c|}{0.0229} & \multicolumn{2}{|c|}{$<0.0001$} & \multicolumn{2}{|c|}{0.0003} \\
\hline & $\mathrm{B}-\mathrm{O}_{2} /$ Steam & \multicolumn{2}{|c|}{0.0006} & \multicolumn{2}{|c|}{0.7388} & \multicolumn{2}{|c|}{0.0492} & \multicolumn{2}{|c|}{$<0.0001$} & \multicolumn{2}{|c|}{0.0018} \\
\hline & $\mathbf{A B}$ & \multicolumn{2}{|c|}{-} & \multicolumn{2}{|c|}{0.8713} & \multicolumn{2}{|c|}{-} & \multicolumn{2}{|c|}{$<0.0001$} & \multicolumn{2}{|c|}{0.5420} \\
\hline & $\mathbf{A}^{2}$ & \multicolumn{2}{|c|}{-} & \multicolumn{2}{|c|}{$<0.0001$} & \multicolumn{2}{|c|}{-} & \multicolumn{2}{|c|}{0.1234} & \multicolumn{2}{|c|}{0.0017} \\
\hline & $\mathbf{B}^{2}$ & \multicolumn{2}{|c|}{-} & \multicolumn{2}{|c|}{0.0076} & & & 0.0 & & 0.4 & 035 \\
\hline & R-Squared & & & 0.9 & & & & 0.9 & & 0.9 & 992 \\
\hline & $\begin{array}{c}\text { Suggested } \\
\text { Model }\end{array}$ & $2 \mathrm{FI}$ & $\begin{array}{c}< \\
0.0001\end{array}$ & Linear & $\begin{array}{c}< \\
0.0001\end{array}$ & $2 \mathrm{FI}$ & $<0.0001$ & $2 \mathrm{FI}$ & 0.0015 & $2 \mathrm{FI}$ & $<0.0001$ \\
\hline & A - \% SG & $<0$ & & $<0$. & & & 001 & 0.0 & & $<0$. & 001 \\
\hline $\mathbf{L G}+\mathbf{S G}$ & $\mathrm{B}-\mathrm{O}_{2} /$ Steam & & & 0.9 & & & 14 & 0.0 & & 0.0 & 002 \\
\hline & $\mathbf{A B}$ & & & . & & & 250 & 0.0 & & 0.0 & 021 \\
\hline & R-Squared & & & 0.9 & & & 571 & 0.9 & & 0.9 & 978 \\
\hline
\end{tabular}


Table 6: Comparison of Isotopic Equilibrium Temperatures of $\mathrm{CO}_{2}-\mathrm{CO}$ Product Gases and Experimental Gasifier Temperatures

\begin{tabular}{|c|c|c|c|c|c|c|}
\hline \multirow[b]{2}{*}{$\mathrm{O}_{2}:$ Steam } & \multirow{2}{*}{$\begin{array}{c}\% \mathrm{CS} \\
\text { Added } \\
\text { to SB }\end{array}$} & \multicolumn{2}{|c|}{ Temperature, ${ }^{\circ} \mathbf{C}$} & \multirow{2}{*}{$\begin{array}{c}\text { \% CS } \\
\text { Added } \\
\text { to LG }\end{array}$} & \multicolumn{2}{|c|}{ Temperature, ${ }^{\circ} \mathbf{C}$} \\
\hline & & Gasifier & Equilibrium & & Gasifier & Equilibrium \\
\hline 2 & & 1055.4 & 1089.8 & & 1081.3 & 1029.5 \\
\hline 1 & 10 & 900.8 & $>1300$ & 10 & 1010.9 & $>1300$ \\
\hline 0.5 & & 853.5 & $>1300$ & & 912.9 & $>1300$ \\
\hline 2 & & 1029.3 & 1090.6 & & 1041.5 & 1002.9 \\
\hline 1 & 20 & 894.1 & $>1300$ & 20 & 890.9 & $>1300$ \\
\hline 0.5 & & 825.6 & $>1300$ & & 852.1 & $>1300$ \\
\hline 2 & & 900.7 & 1143.1 & & 883.2 & 1078.2 \\
\hline 1 & 30 & 867.8 & $>1300$ & 30 & 826.2 & $>1300$ \\
\hline 0.5 & & 803.3 & $>1300$ & & 739.7 & $>1300$ \\
\hline $\mathrm{O}_{2}$ :Steam & $\begin{array}{c}\% \text { SG } \\
\text { Added } \\
\text { to SB }\end{array}$ & \multicolumn{2}{|c|}{ Temperature, ${ }^{\circ} \mathbf{C}$} & $\begin{array}{c}\% \text { SG } \\
\text { Added } \\
\text { to LG }\end{array}$ & \multicolumn{2}{|c|}{ Temperature, ${ }^{\circ} \mathbf{C}$} \\
\hline & & Gasifier & Equilibrium & & Gasifier & Equilibrium \\
\hline 2 & & 1010.6 & $>1300$ & & 1037.3 & $>1300$ \\
\hline 1 & 10 & 962.1 & $>1300$ & 10 & 995.2 & $>1300$ \\
\hline 0.5 & & 901.1 & $>1300$ & & 908.1 & $>1300$ \\
\hline 2 & & 959 & $>1300$ & & 927.7 & $>1300$ \\
\hline 1 & 20 & 933 & $>1300$ & 20 & 847.3 & $>1300$ \\
\hline 0.5 & & 879.1 & $>1300$ & & 811.3 & $>1300$ \\
\hline 2 & & 912.8 & $>1300$ & & 882.1 & $>1300$ \\
\hline 1 & 30 & 899.7 & $>1300$ & 30 & 733.4 & $>1300$ \\
\hline 0.5 & & 823.5 & $>1300$ & & 680.9 & $>1300$ \\
\hline
\end{tabular}




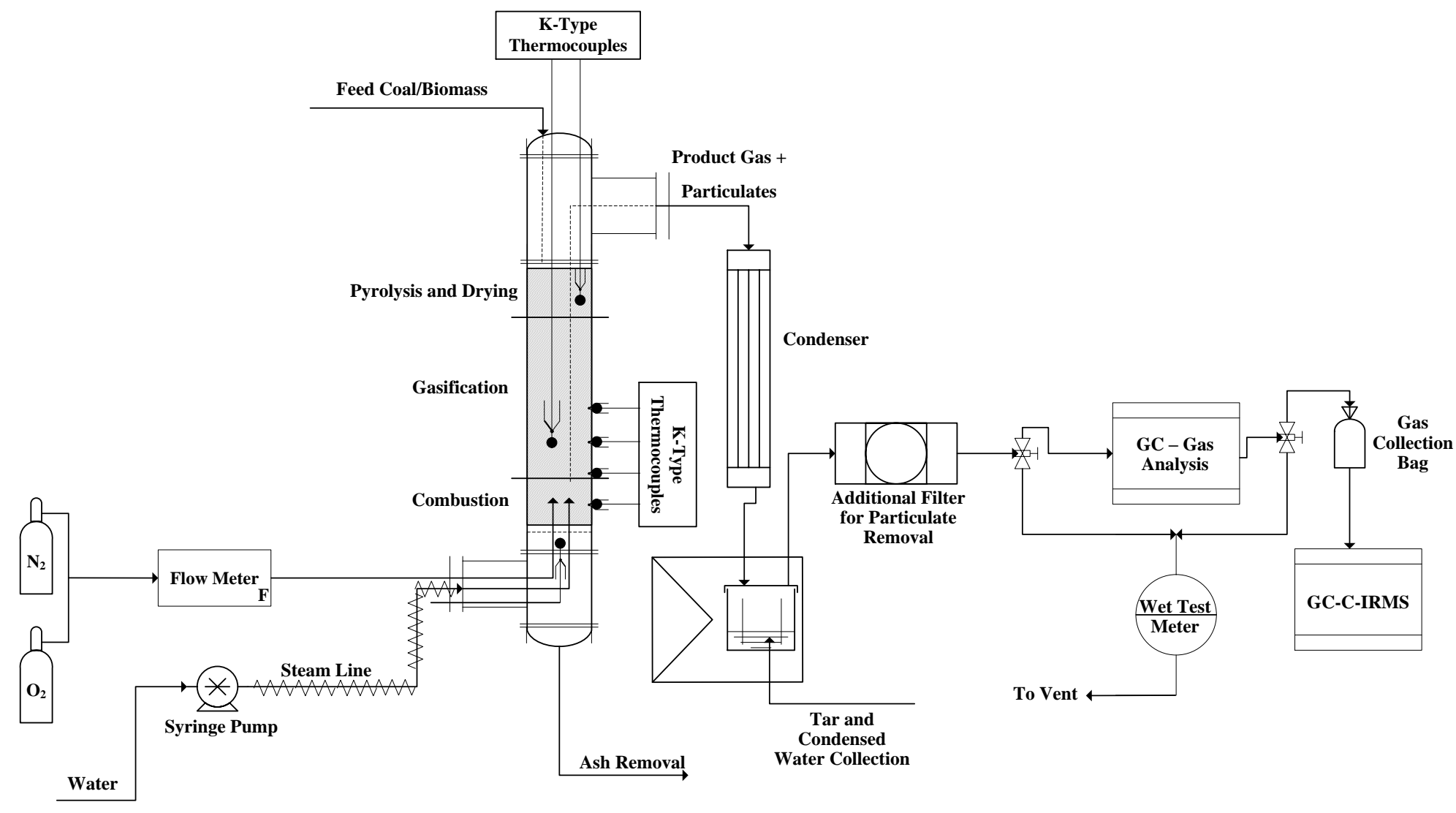

Figure 1: Schematic of the Laboratory Scale Moving Bed Gasification System for Gasifying Mixtures of Coal and Biomass 
- Oxygen $/$ Steam $=2.0 \quad$ Oxygen $/$ Steam $=1.0 \quad \Delta \quad$ Oxygen $/$ Steam $=0.5$
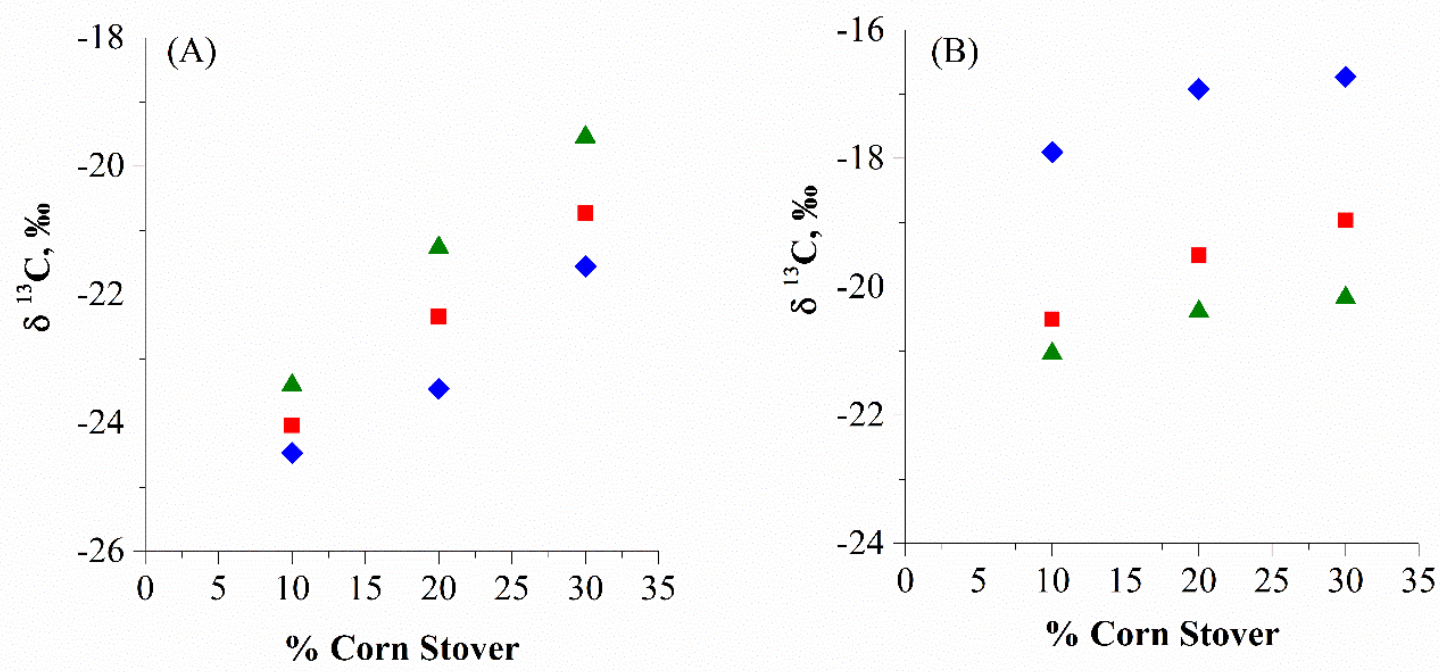

Figure 2: Effect of increasing percentage of corn stover and varying oxygen/steam ratios on the isotopic signatures of product gases in its blends with DECS-38 sub-bituminous coal. (A) Isotopic Signature of $\mathrm{CO}$, (B) Isotopic Signature of $\mathrm{CO}_{2}$. 
- Oxygen $/$ Steam $=2.0 \quad$ Oxygen $/$ Steam $=1.0 \quad$ ॥ Oxygen $/$ Steam $=0.5$
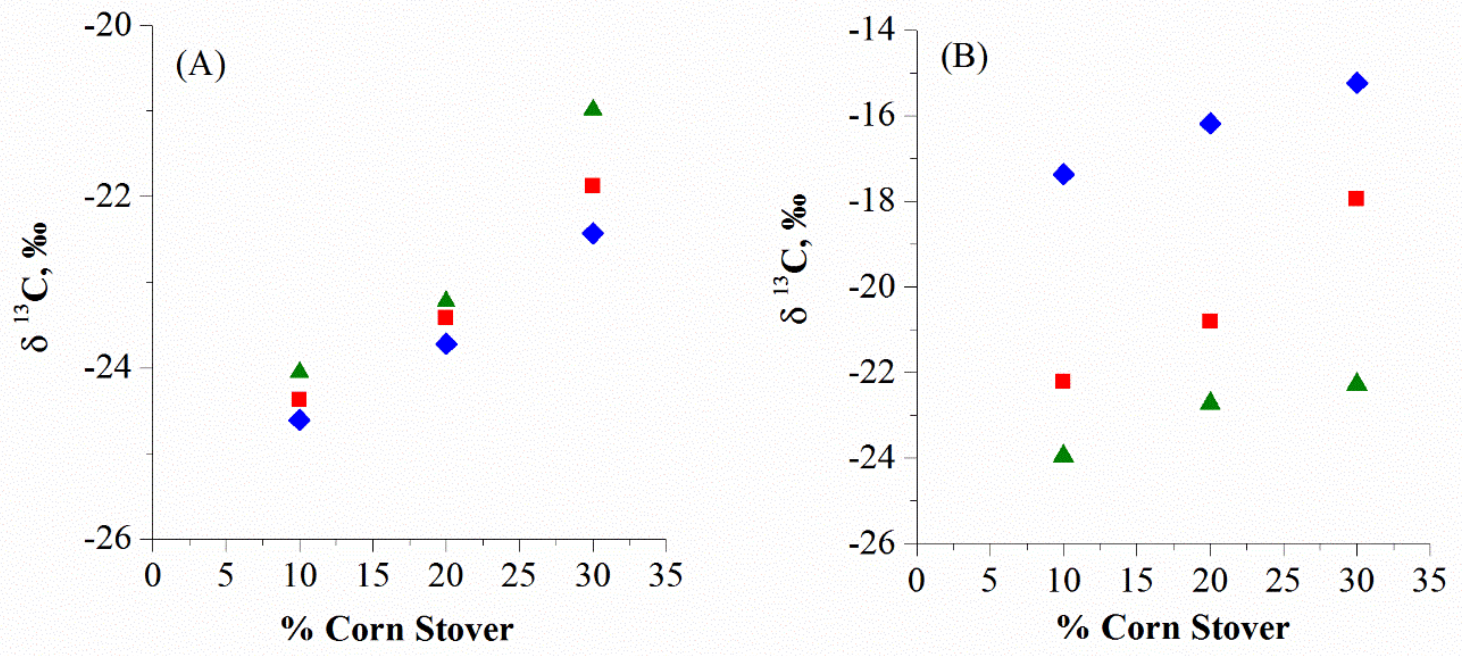

Figure 3: Effect of increasing percentage of corn stover and varying oxygen/steam ratios on the isotopic signatures of product gases in its blends with DECS-25 lignite coal. (A) Isotopic Signature of $\mathrm{CO}$, (B) Isotopic Signature of $\mathrm{CO}_{2}$. 
- Oxygen $/$ Steam $=2.0 \quad$ Oxygen $/$ Steam $=1.0 \quad \Delta \quad$ Oxygen $/$ Steam $=0.5$
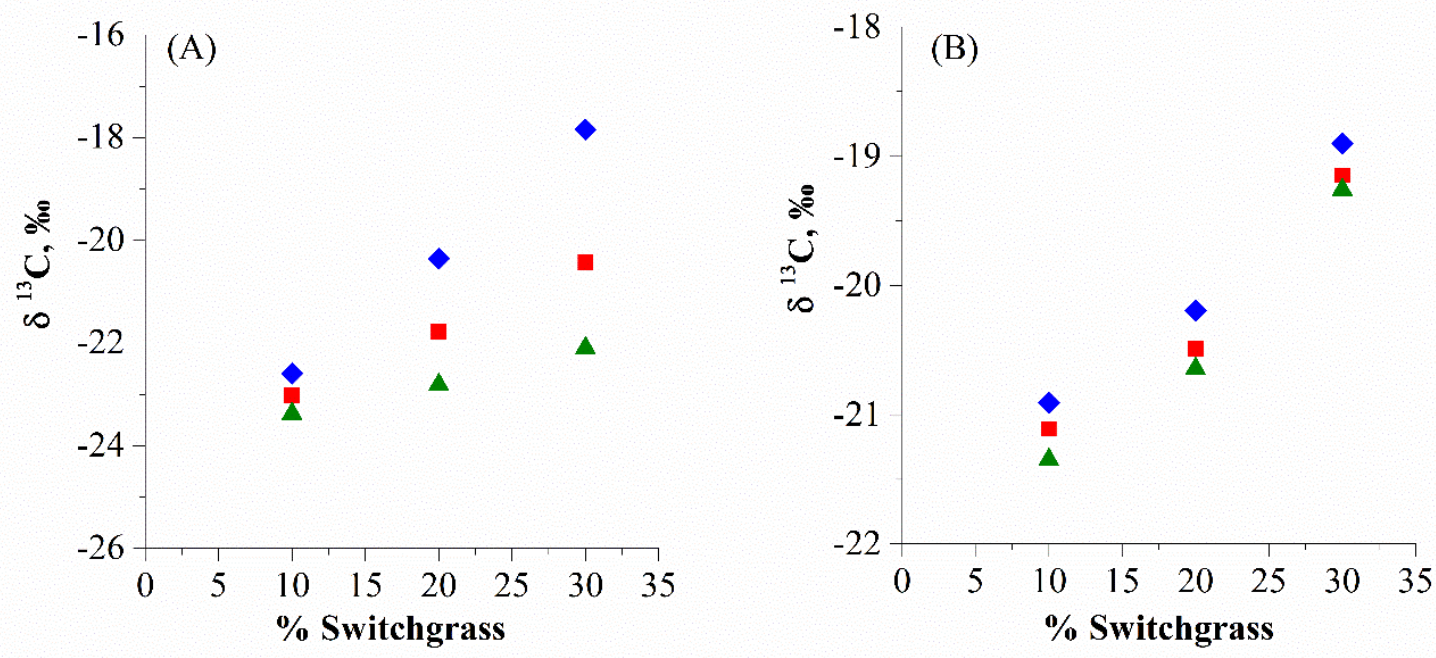

Figure 4: Effect of increasing percentage of switchgrass and varying oxygen/steam ratios on the isotopic signatures of product gases in its blends with DECS-38 sub-bituminous coal. (A) Isotopic Signature of $\mathrm{CO},(\mathrm{B})$ Isotopic Signature of $\mathrm{CO}_{2}$. 


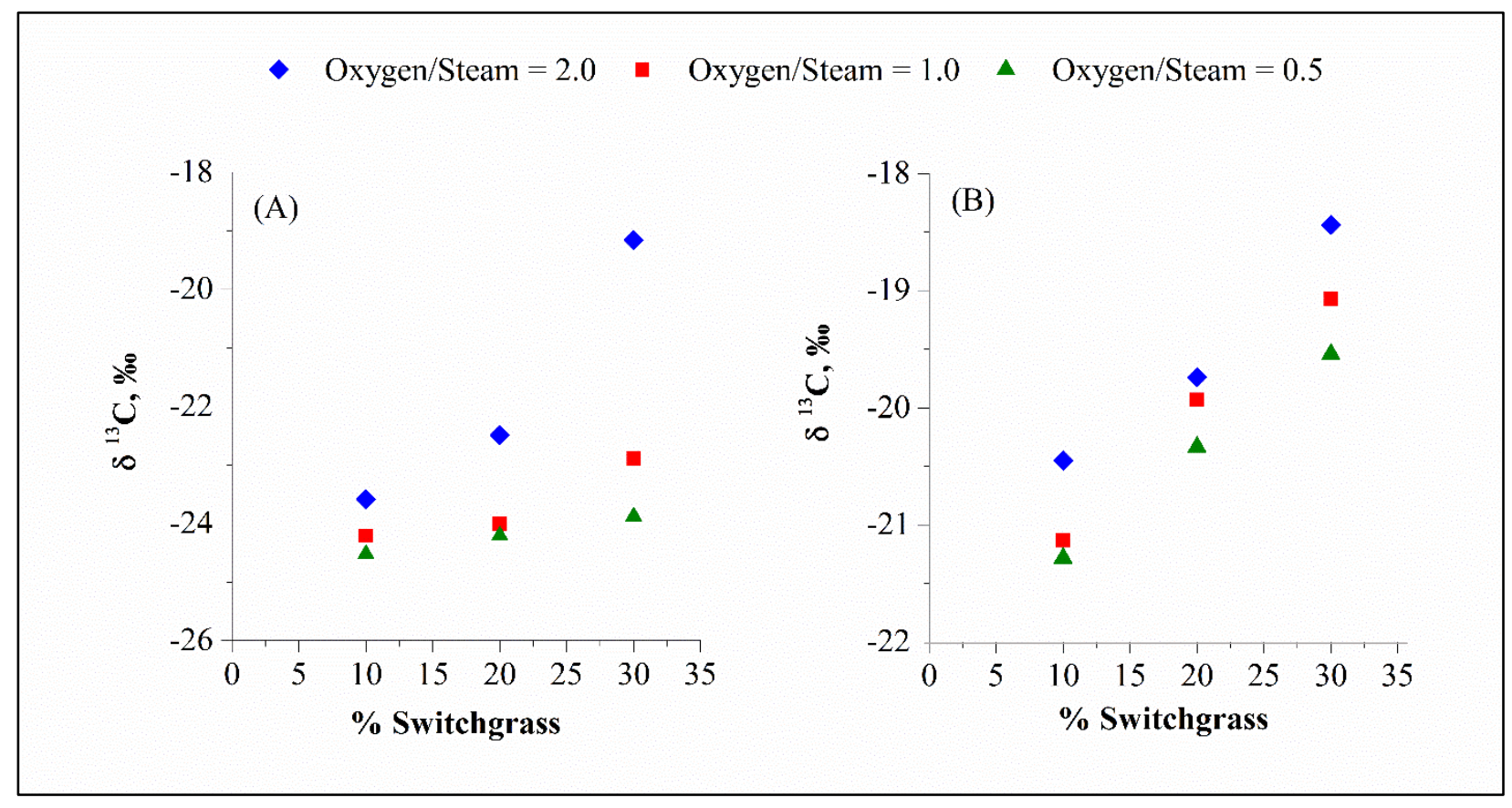

Figure 5: Effect of increasing percentage of switchgrass and varying oxygen/steam ratios on the isotopic signatures of product gases in its blends with DECS-25 lignite coal. (A) Isotopic Signature of $\mathrm{CO},(\mathrm{B})$ Isotopic Signature of $\mathrm{CO}_{2}$. 


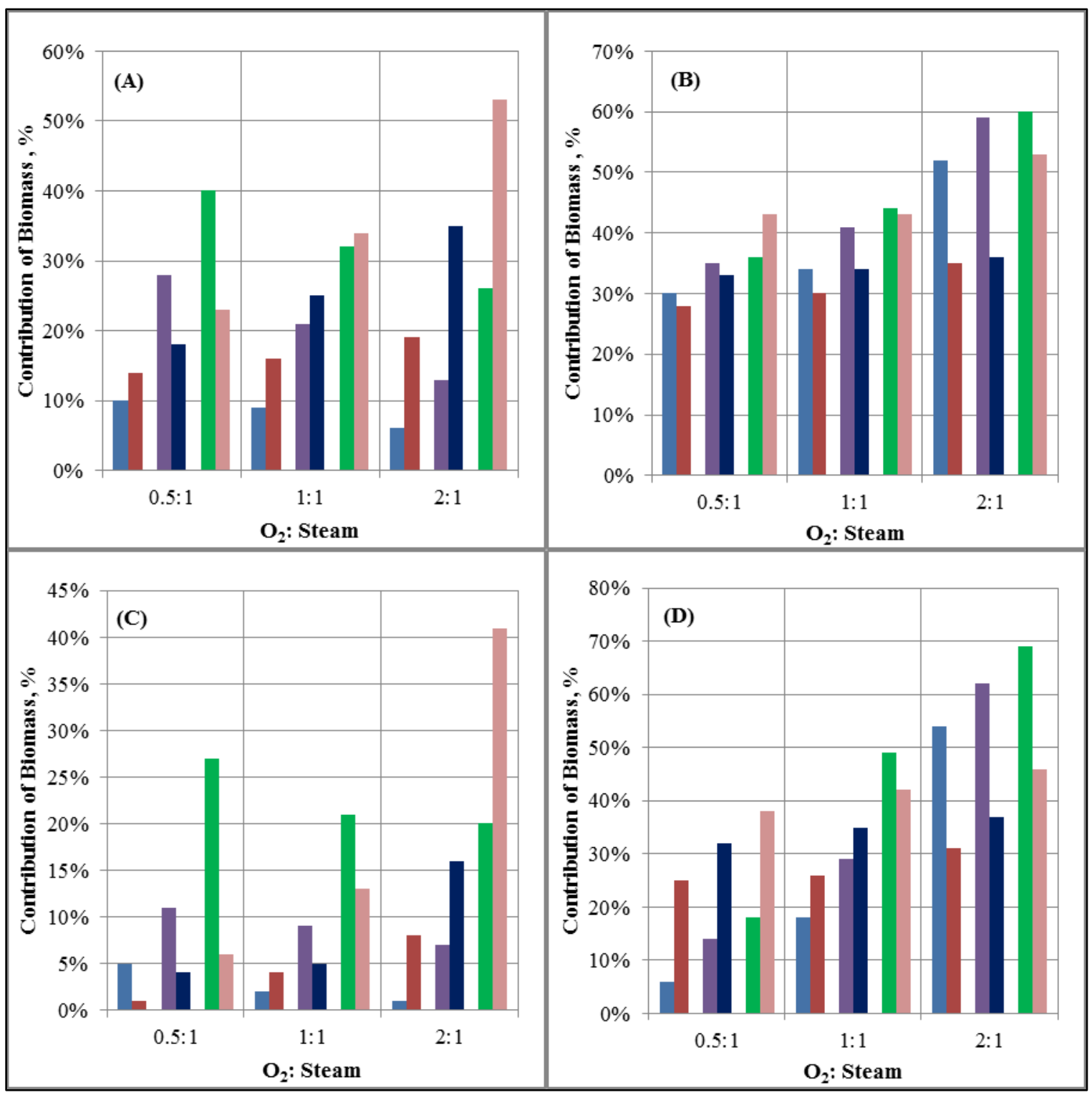

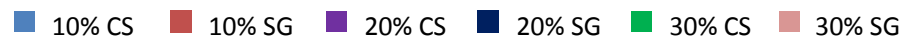

Figure 6: Individual contribution of each biomass source towards generation of product gases at different $\mathrm{O}_{2} /$ steam ratios. (A) Contribution in the generation of $\mathrm{CO}$ in blends with DECS-38 sub-bituminous coal, (B) Contribution in the generation of $\mathrm{CO}_{2}$ in blends with DECS-38 sub-bituminous coal, $(\mathrm{C})$ Contribution in the generation of $\mathrm{CO}$ in blends with DECS-25 lignite coal, and (D) Contribution in the generation of $\mathrm{CO}_{2}$ in blends with DECS25 lignite coal. 